\title{
Establishment and characterization of two primary breast cancer cell lines from young Indian breast cancer patients: mutation analysis
}

Santhi Latha Pandrangi ${ }^{1+}$, Sarangadhara Appala Raju Bagadi ${ }^{1}$, Navin Kumar Sinha ${ }^{2}$, Manoj Kumar ${ }^{3}$, Rima Dada ${ }^{3}$, Meena Lakhanpal ${ }^{1}$, Abha Soni', Shreshtha Malvia', Sheeba Simon' ${ }^{1}$, Chintamani Chintamani ${ }^{4}$, Ravindar Singh Mohil ${ }^{4}$, Dinesh Bhatnagar ${ }^{4}$ and Sunita Saxena ${ }^{1^{*}}$

\begin{abstract}
Two novel triple negative breast cancer cell lines, NIPBC-1 and NIPBC-2 were successfully established from primary tumors of two young breast cancer patients aged 39 and 38 years respectively, diagnosed as infiltrating duct carcinoma of breast. Characterization of these cell lines showed luminal origin with expression of epithelial specific antigen and cytokeratin 18 and presence of microfilaments and secretary vesicles, microvilli, tight junctions and desmosomes on ultra-structural analysis. Both the cell lines showed anchorage independent growth and invasion of matrigel coated membranes. Karyotype analysis showed aneuploidy, deletions and multiple rearrangements in chromosomes 7, 9, X and 11 and isochromosomes 17q in both the cell lines. P53 mutational analysis revealed no mutation in the coding region in both the cell lines; however NIPBC-2 cell line showed presence of heterozygous C/G polymorphism, g.417 C > G (NM_000546.5) resulting in Arg/Pro allele at codon 72 of exon 4. Screening for mutations in BRCA1\&2 genes revealed presence of three heterozygous polymorphisms in exon 11 of BRCA1 and 2 polymorphisms in exons 11, and14 of BRCA2 gene in both the cell lines. Both the cell lines showed presence of CD 44+/24-breast cancer stem cells and capability of producing mammosphere on culture. The two triple negative breast cancer cell lines established from early onset breast tumors can serve as novel invitro models to study mechanisms underlying breast tumorigenesis in younger age group patients and also identification of new therapeutic modalities targeting cancer stem cells.
\end{abstract}

Keywords: Breast cancer, Breast cancer cell line, Establishment

\section{Introduction}

Breast cancer is the leading cause of cancer deaths among women, accounting for $23 \%$ of the total cancer incidence and $14 \%$ cancer deaths globally [1]. In India breast cancer has emerged as most common cancer in women, which was earlier reported as second most common cancer after cancer of cervix [2], the age adjusted annual incidence rate (AAR) ranging from 25-33 cases per 100,000 women in urban population and 7.2 in rural areas [2]. Around 100,000 women are diagnosed with

\footnotetext{
* Correspondence: sunita_saxena@yahoo.com

${ }^{\dagger}$ Equal contributors

${ }^{1}$ National Institute of Pathology (ICMR), Safdarjung Hospital Campus, New Delhi 110029, India

Full list of author information is available at the end of the article
}

carcinoma breast every year in India, of which around 50,000 women die with the disease every year with a predicted rise to 131000 cases by 2020, and increased concentration in urban areas [3]. The incidence of breast cancer in Indian population (1/35) is not as high as in the western countries $(1 / 8)$ however, the incidence of early onset of breast cancer cases ( $<40$ years) does not show significant variation in women worldwide (12-33 per 100,000 women); suggesting that a greater proportion of all breast cancers is mainly due to early onset of disease in Indian population [1,4]. The average age of onset of breast cancer in Indian patients ranges between 40-50 years compared to 60-70 in western countries. Breast cancer diagnosed at young age is well recognized as clinically different than breast cancers diagnosed at older ages [5]. Younger patients more frequently exhibit 
aggressive features such as large tumor size, high histological grade, positive lymph nodes, absence of steroid receptors and high S-phase fraction, and young age itself has been shown to be an independent predictor of adverse prognosis [6-9]. Majority of Indian breast cancer patients are young $(<40 \mathrm{yrs})$, married and having children at younger age with history of breast feeding their children for long duration. The development of breast cancer in these young women is an enigma. There is not much information available regarding the molecular mechanism and etiological factors responsible for the breast cancer at young age; hence there is a need for establishing an experimental tool to investigate it.

Cell lines provide an important experimental tool in cancer research with major benefit of infinite supply of a relatively homogeneous cell population that is capable of self-replication which can be widely distributed to facilitate comparative studies. Cell cultures established directly from human tumors serve as unique models for studying and manipulating the potentially relevant molecular and cellular processes underlying malignant disease and identification of novel biological therapeutic targets. Majority of breast cancer derived cell lines are from secondary tumours and pleural effusions of patients with advanced stage breast cancers [10-18]. Few breast cancer cell lines have been successfully established from primary tumours [19-24]. Among the available breast cancer cell lines, majority of cell lines are established from cancers from older age group patients (> $55 \mathrm{yrs}$ ), only a small proportion of breast cancer cell lines are established from patients $<40$ years of age. To establish a tool to elucidate the molecular pathogenesis of breast cancer in young Indian women who usually exhibit major reproductive protective factors for breast cancer, we have established two breast cancer cell lines, NIPBC-1 and NIPBC-2 from primary tumours of two young breast cancer patients $(<40 \mathrm{yrs})$. These two cell lines are triple negative which is most common phenotype seen in breast tumours in young women.

\section{Materials and methods}

\section{Establishment and purification of primary cultures}

Primary cultures were established from tumour tissue obtained from breast cancer patients, who underwent modified radical mastectomy (MRM) or tru-cut biopsies at Safdarjung hospital, New Delhi, India. A part of biopsy was used for frozen section/paraffin embedding to confirm the diagnosis and presence of tumor cells in it. The tumour tissue was collected in DMEM supplemented with antibiotics (penicillin $100 \mathrm{U} / \mathrm{ml}$, streptomycin $100 \mu \mathrm{g} / \mathrm{ml}$ ). The tissue was then washed with PBS supplemented with antibiotics, minced into 1-2 cu.mm pieces removing blood, fat and fibro connective tissue used for enzymatic disaggregation. Enzymatic disaggregation was carried out by incubating the small tissue pieces with $2.5 \%$ crude trypsin for 30 minutes at $37^{\circ} \mathrm{C}$ and with collagenase $(0.15 \%)$ overnight. Cells released after enzymatic treatment were tested for cell viability using trypan blue and then seeded on to tissue culture flasks and maintained in DMEM medium supplemented with 10-20\% FBS, Glutamine $2 \mathrm{mM}$, and growth factors such as epidermal growth factor $(5-15 \mathrm{ng} / \mathrm{ml})$ insulin $100 \mathrm{U} / \mathrm{ml}$. The cells were then maintained in DMEM medium supplemented with $10 \% \mathrm{FBS}$ and growth factors at $37^{\circ} \mathrm{C}$ in a humidified atmosphere of $5 \% \mathrm{CO}_{2}$ and $95 \%$ air. Growth factors were gradually withdrawn from the primary cultures after their purification and were presently being maintained in DMEM medium supplemented with $10 \%$ FBS and $2 \mathrm{mM}$ Glutamine. Once the cultures were 80- $90 \%$ confluent, the cells were trypsinised with $0.05 \%$ trypsin and split in a ratio of $1: 3$ in fresh DMEM medium. Also, the cells were sampled and frozen periodically at various passages. Both NIPBC-1 and NIPBC2 were completely purified and passaged for 85 and 66 times respectively and characterised thoroughly.

\section{Characterisation of established cell lines Phenotypic characterization}

(i) Immunoflourescence

For immonocytochemical analysis cells were grown on cover slips, fixed with methanol-acetone/ $4 \%$ paraformaldehyde and incubated with monoclonal antibodies for Estrogen receptor (ER), Progesterone receptor (PR), HER2/neu, Pan-Cytokeratin, Cytokeratins 5/6 and 18, vimentin, epithelial membrane antigen (EMA), Mucin 1 and P53. These cover slips were further incubated with secondary antibody conjugated with FITC (DAKO) and counterstained with propidium iodide (Sigma). Fluorescence was detected using fluorescence microscope.

(ii) Flowcytometry

Cells were trypsinised to form a single cell suspension, counted and washed with ice cold staining buffer (1× PBS with 3\% FBS and 0.05\% sodium azide). Approximately, $1 \times 10^{6}$ cells were resuspended in $500 \mu \mathrm{l}$ of ice cold staining buffer and $3 \mu \mathrm{l}$ of FITC conjugated Ki67 or primary antibodies of p53 were added and incubated for 30 minutes at $4^{\circ} \mathrm{C}$ in dark. The cells were then washed and incubated subsequently with FITC conjugated secondary antibodies (for P53 and P21). After incubation the cells were washed twice by centrifugation at $400 \mathrm{~g}$ for 5 minutes and resuspended in $1 \mathrm{ml}$ of ice cold staining buffer and kept on ice until analysis. Appropriate isotype controls have been used. 


\section{Ultrastructure analysis of the cells}

For ultrastructure studies, cultured cells were double fixed with $1.2 \%$ glutaraldehyde in $0.01 \mathrm{M}$ phosphate-buffered saline $(\mathrm{pH} 7.5)$ and with $2.0 \%$ glutaraldehyde for $1 \mathrm{hr}$ at $4^{\circ} \mathrm{C}$. Post-fixation was performed with $1 \% \mathrm{OsO} 4$. The sample was embedded in epoxy resin. The ultra- thin sections were cut (400-500 $\mu$ ), stained by lead citrate and uranyl acetate and studied under transmission microscope [25].

\section{Softagar assay}

The ability of anchorage-independent growth of the purified cancer epithelial cells was determined by growing the cells on semisolid agar at 25th and at 40th passages. A single-cell suspension containing $10^{5}$ cells/35-mm petri dish was dispersed in a solution containing $0.3 \%$ bactoagar in epithelial culture medium described above. This was then layered over a $0.6 \%$ bacto-agar solution in DMEM/F12 supplemented with 10\% FBS and fed biweekly with epithelial cell culture medium. Formation of colonies was determined by inverted microscopy for 2-3 weeks post-seeding [26].

\section{Karyotyping}

Karyotyping of both NIPBC-1 and NIPBC-2 cell lines has been done at both early passages (P20 and P15 respectively) and late passages (P65 and P52 respectively) to facilitate cytogenetic examination and comparison of the karyotypes between early and late passages. Briefly, cells were plated at approximately $1-2 \times 10^{6} / 75 \mathrm{~cm}^{2}$ flask. After $48 \mathrm{hrs}$ cells were exposed to $0.1 \mu \mathrm{g}$ of colchicine (Sigma) at $37^{\circ} \mathrm{C}$, for $3 \mathrm{hrs}$. The cells were then harvested by trypsinization, incubated for 20 minutes at room temperature with a hypotonic solution $(75 \mathrm{mM}$ KCL) and fixed with methanol: acetic acid (3:1). Slides were prepared and stained with GIEMSA. G banding was done to analyse chromosomal aberrations [27].

\section{Population doubling time}

The doubling time of both NIPBC- 1 and NIPBC- 2 cell lines at passage 35 and 32 respectively, was determined by counting the cell number at regular intervals. On day $0,1 \times 10^{5}$ viable cells were seeded in triplicate in each of six well plates (corning, USA) in DMEMF12 culture medium. Cells were counted in triplicate with a Neubauer chamber at exactly $24 \mathrm{hr}$ intervals for a series of 10 days after staining with trypan blue dye. The growth curve was plotted and the doubling time was calculated from regression equation of the curve [28-31].

\section{DNA finger printing/STR profiling}

STR profiling of NIPBC-1 and NIPBC-2 cell lines was done using StemElite ID System kit (Promega) as per the manufacturer's instructions. This method allows identification of unique detection of short tandem repeats, seven human STR loci, Amelogenin (for gender identification) and one mouse locus, which include TPOX, vWA, Amelogenin,
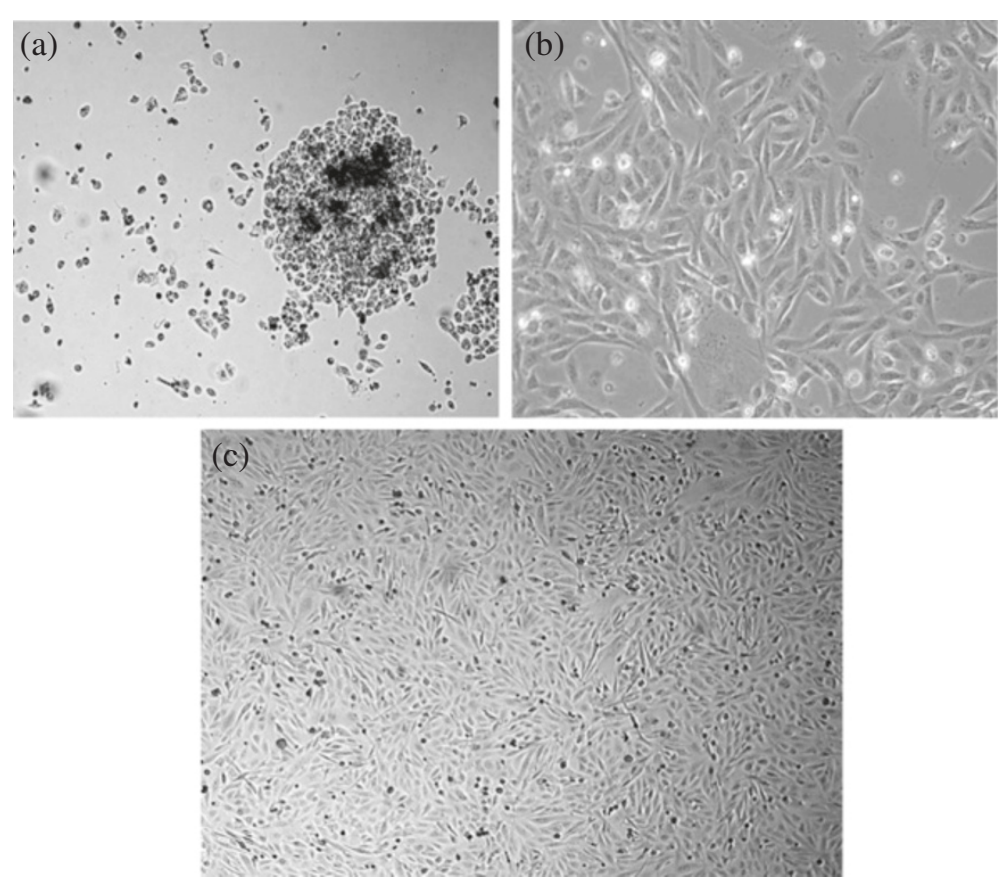

Figure 1 Establishment of NIPBC-1 cell line showing stages of (a) Initiation (b) purification and (c) completely purified confluent NIPBC-1 cell line. 
CSF1PO, D16S539, D7S820, D13S317, D5S818 and MUS. These loci collectively provide a genetic profile with a random match probability of 1 in $2.92 \times 10^{9}$ (while simultaneously providing detection of a $1 \%$ fraction of mouse contaminant in a human cell line). The eleven loci are amplified simultaneously in a single tube and analyzed by capillary electrophoresis on 3130xl genetic analyzer (Applied Biosystems, Foster City, CA, USA).

\section{Invasion assay}

To assess the invasive capacity of NIPBC-1 and NIPBC2 cells, we utilized Corning invasion chambers and coated them with matrigel; MDA-MB-231 cells were used as positive control. Cells were trypsinised and washed twice with PBS before they are transferred to the invasion chamber. Prior to use, chambers were rehydrated with DMEM for 2 hours at $37^{\circ} \mathrm{C}$ then plated with $5 \times 10^{4}$ cells per well. After 12 hours of incubation, invasion chambers were fixed in $4 \%$ paraformaldehyde for 15 minutes, stained with hematoxylin, and washed in PBS. Cancer cells that invaded through the matrigelcoated filter on the lower membrane were manually counted under a microscope. Four randomly chosen fields were counted for each well. The experiment was performed in triplicates.

\section{Mycoplasma detection}

The mycoplasma DNA was detected by the PCR kit Venor GeM (Minerva Biolabs) as per the manufacturer's instructions. This kit is specific for a spectrum of contaminants of cell lines and their biological derivatives belonging to Mycoplasma acholeplasma and ureaplasma species. The primer set is specific to the highly conserved $16 \mathrm{~S}$ rRNA coding region in the mycoplasma genome. Detection requires as little as 1-5 fg of mycoplasma DNA corresponding to 2-5 mycoplasma per sample volume. The resulting PCR products were separated by electrophoresis in $1.5 \%$ agarose gel, stained with ethidium bromide, visualized under UV light and documented by photography.

\section{BRCA1 \& 2 mutational screening}

The complete coding regions and exon-intron boundaries for BRCA1 gene were screened for DNA sequence variants by automated sequencing on $3130 \times 1$ genetic analyzer (Applied Biosystems, Foster City, CA, USA). DNA was isolated from both the cell lines. $100 \mathrm{ng}$ of genomic DNA was used for PCR amplification with BRCA1\&2 specific primers as mentioned in Saxena et.al. (2006) [32].

\section{Mutational analysis of TP53}

Genomic DNA was isolated from NIPBC-1 and NIPBC-2 cell lines using Gene aid DNA isolation kit as per the manufacturer's instructions. Polymerase chain reaction (PCR) amplified products encompassing exons 2- 3, 4, $5-6,7,8,9,10$ and 11 of the TP53 gene were analyzed for mutations by automated sequencing using 3130xl genetic analyzer (Applied Biosystems, Foster City, CA, USA).
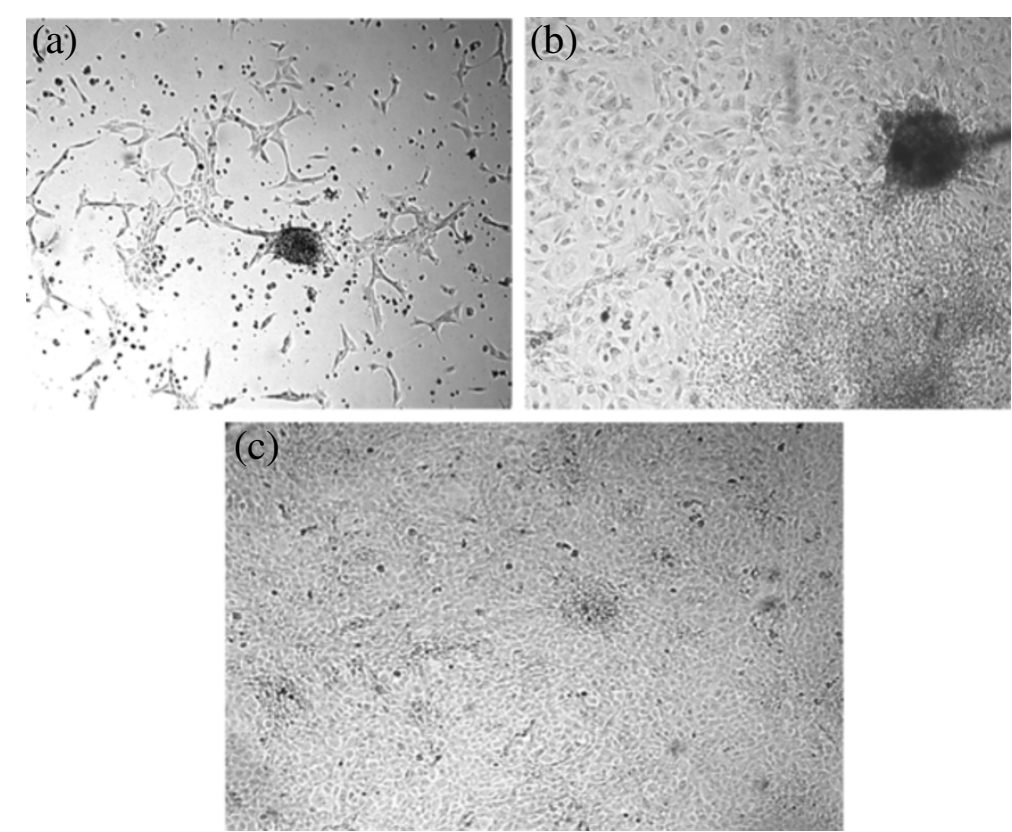

Figure 2 Establishment of NIPBC-2 cell line showing stages of (a) Initiation (b) purification and (c) completely purified confluent NIPBC-2 cell line growing in layers. 


\section{Study of stem cell population}

(i) Aldefluor assay and flow cytometry Aldefluor assay was performed as per the manufacturer's instructions (StemCell Technologies, Vancouver, BC, Canada) in NIPBC-1, NIPBC-2 and MCF7 breast cancer cell lines. Briefly, single cells obtained from cell cultures were incubated in Aldefluor assay buffer containing an ALDH substrate, bodipy-aminoacetaldehyde (BAAA, $1 \mu \mathrm{mol} / \mathrm{L}$ per $1,000,000$ cells), for $30 \mathrm{~min}$ at $37^{\circ} \mathrm{C}$. A fraction of cells from each sample, incubated under identical condition in the presence of diethylaminobenzaldehyde (DEAB) was taken as negative control [33]. Flow cytometry was conducted using FACS ARIA II SORP (Special order research product) (Becton Dickinson). ALDEFLUOR florescence was excited at $488 \mathrm{~nm}$ and florescence emission was detected using a standard FITC 530/30 band pass filter. The sorting gates were established using the negative control $[34,35]$.

(ii) Identification of $\mathrm{CD} 44^{+} / \mathrm{CD} 24^{-}$breast cancer stem cells by flow cytometry
$\mathrm{Al}-$ Hajj and collegues have demonstrated that expression of stem-cell markers CD $44^{+} / \mathrm{CD} 24^{-/ \text {low }}$ in mammary tumors has prognostic significance [36]. Breast cancer cell line MCF7 was taken as a positive control. To sort tumor cells with CD44 and CD24 markers both NIPBC-1 and NIPBC-2 cell lines were trypsinized to make single cell suspensions. Approximately, $1 \times 10^{7}$ cells suspended in $1 \mathrm{ml}$ of staining buffer were stained with fluorochrome conjugated monoclonal antibodies against human CD44 (PE) and CD24 (FITC) both individually and in combinations. The isotype controls were also added to the cell suspensions as per the manufacturer's instructions and were incubated in the dark for $45 \mathrm{~min}$. Unbound antibody was washed off and cells were analyzed for the presence of $\mathrm{CD} 44^{+} / \mathrm{CD} 24^{-}$ cell population, no longer than $2 \mathrm{hr}$ post staining on BD FACS ARIA. The sorting gates were established using the isotype matched controls [36].

This study had been approved by institutional ethics committee of Safdarjung Hospital, New Delhi and consent has been obtained from each patient for participating in this study.
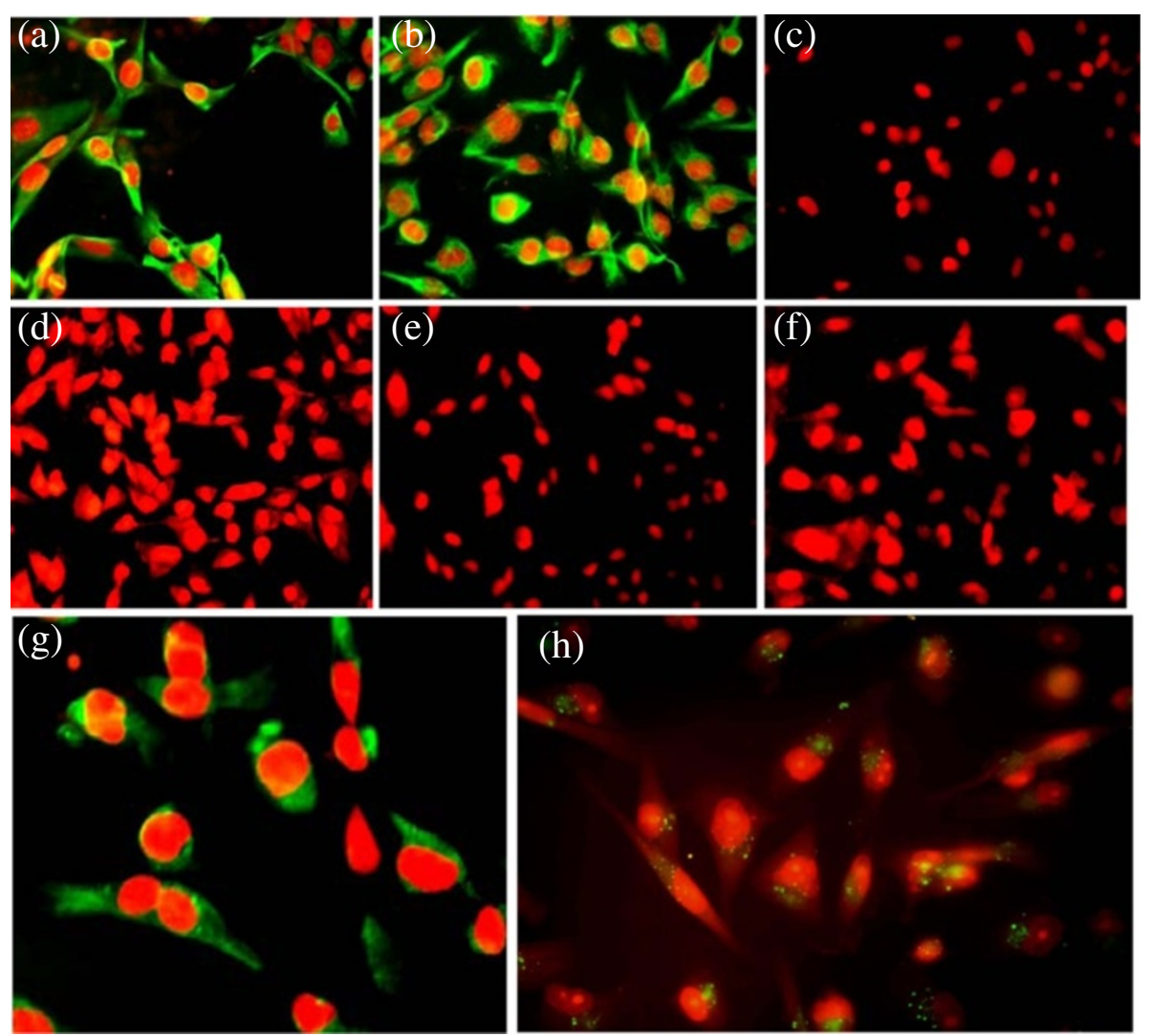

Figure 3 Expression of biological markers in the established breast cancer cell line NIPBC-1. (a) Epithelial membrane antigen, (b) Cytokeratin 18, (c) Cytokeratin 5/6, (d) Estrogen receptor, (e) Progesterone receptor, (f) HER2/neu (g) P53 and (h) Vimentin. 


\section{Results}

\section{Establishment of primary cultures}

We have initiated 31 primary cultures using 44 biopsies obtained from patients diagnosed with carcinoma of breast. Out of these primary cultures, 2 cell lines could be successfully purified and propagated for more than 60 passages. Among the two cell lines established, NIPBC-1 was derived from a breast cancer patient aged 39 years and NIPBC-2 from a 38 year old patient. The breast tumor in both the cases has been diagnosed as Infiltrating breast cancer NOS type, grade IIb and grade III respectively. The two cell lines were established by enzymatic disaggregation followed by differential trypsinization. NIPBC-1 was initiated after enzymatic disaggregation of tumor tissue with trypsin. Cells were seeded onto the surface of a flask and cells which adhered to the surface by day 1 , reached confluency by day 10 ; the cells were then subjected to differential trypsinization, until a pure epithelial cell population is remained in the flask. NIPBC-1 cells are spindle shaped cells which grow sparse, do not grow in layers and adhere strongly to the surface (Figure 1). The second cell line NIPBC-2 was initiated by enzymatic disaggregation with both trypsin and collagenase; the cells adhered to the surface after day 3, and formed cell aggregates consisting of epithelioid cells. These cells proliferated and occupied the whole surface by day 8 . They formed distinct large epithelial colonies surrounded by fibroblasts, which were further enriched by selective scraping of the fibroblasts. NIPBC-2 cells are cuboidal cells which form multilayers. They are fast growing, and easily get detached upon trypsinization. NIPBC-1 and NIPBC-2 cell lines were so far passaged for 85 and 66 times respectively in our laboratory (Figure 2).

\section{Expression of epithelial and biological markers}

Expression of epithelial markers EMA, Cytokeratin-18, 5/6, mesenchymal marker vimentin, Estrogen receptor and P53 was studied in the established cultures by immunoflorescence (Figures 3 and 4) and immunocytochemistry (data not shown) to determine their histogenesis. Both NIPBC-1 and NIPBC-2 cells showed immunonegativity for cytokeratin $5 / 6$ and are found to be nonbasal. Both the cell lines were found to be triple negative (ER -ve, PR -ve and HER2/neu -ve). While the NIPBC-1 cell line showed over expression of cytoplasmic Muc1, but was found p53 negative. NIPBC-2 cell line did not show expression of Muc1 but showed a strong nuclear positivity for p53.

Further we have analyzed expression of cell cycle markers viz., Ki67, p53 and p21 proteins by flow
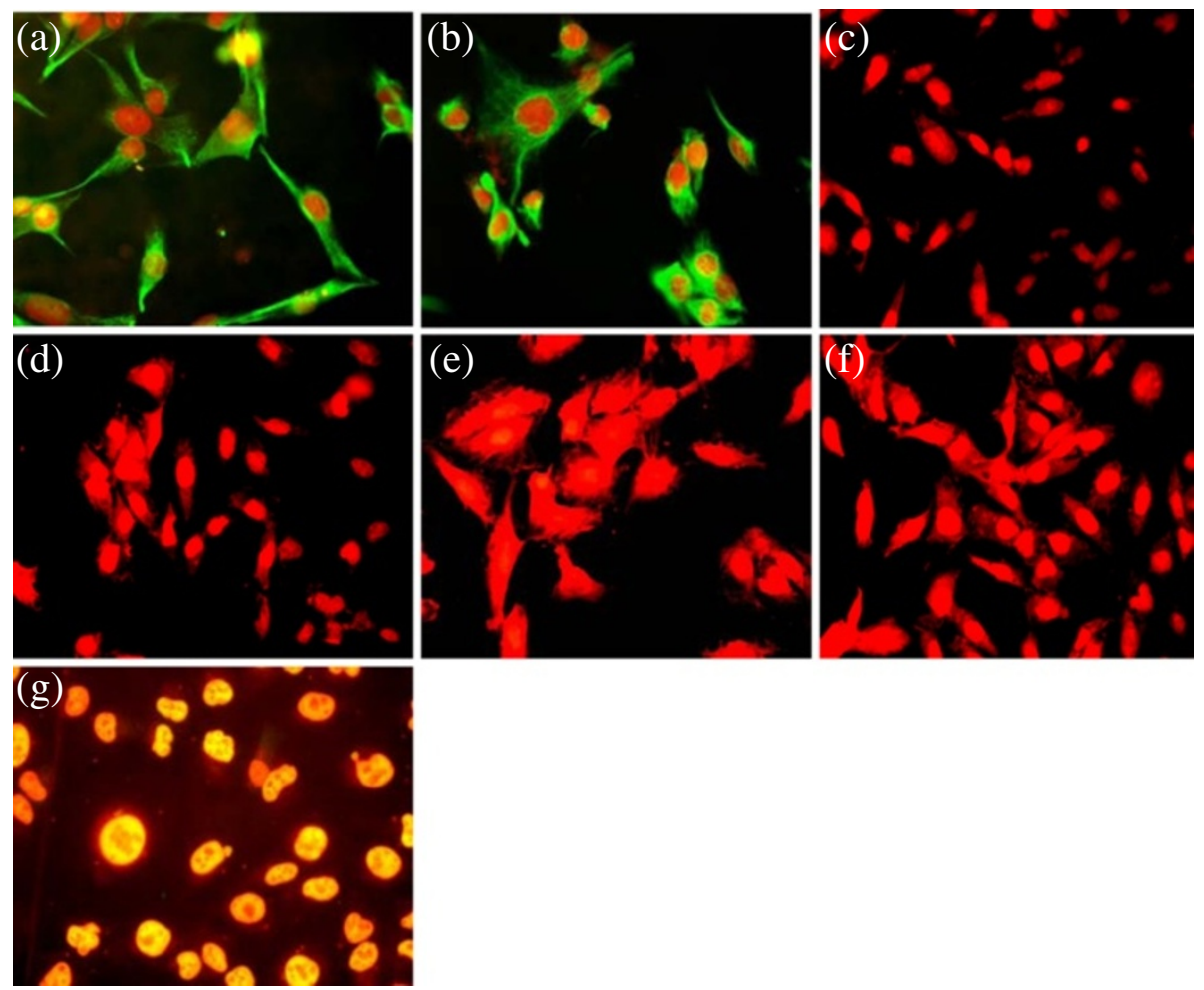

Figure 4 Expression of biological markers in the established breast cancer cell line NIPBC-2. (a) Epithelial membrane antigen, (b) Cytokeratin 18, (c) Cytokeratin 5/6, (d) Estrogen receptor, (e) Progesterone receptor, (f) HER2/neu and (g) P53. 
(a)

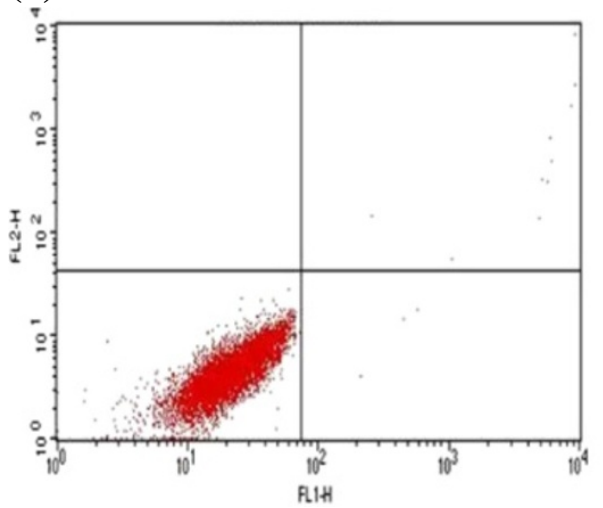

(b)

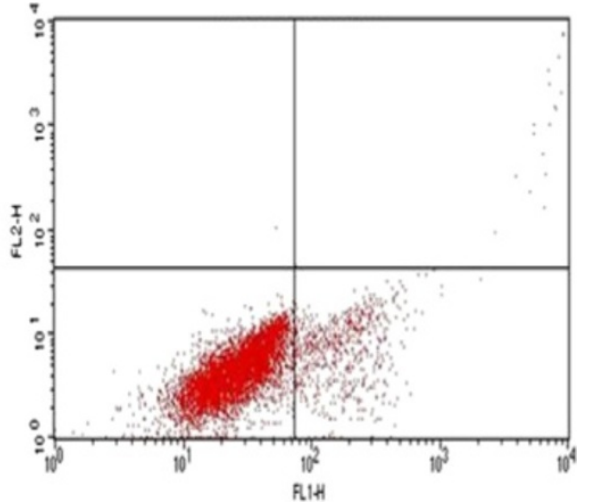

Figure 5 Expression of cell cycle markers by FACS in NIPBC-1 cell line. (a) P53 (0.26\%) and (b) P21 (11.13\%).

cytometry. Ki67 expression was observed in both NIPBC-1 and NIPBC-2 (Additional file 1: Figure S1), whereas p53 expression was found only in NIPBC-2 confirming the immunofluorescence finding. Both the cell lines demonstrated only negligible amounts of p21 (Figures 5 and 6).

\section{Electron microscopic analysis}

The epithelial lineage of both NIPBC-1 and NIPBC-2 cells was further confirmed by ultrastructure study of the cells by transmission electron microscopy. The cells from both the cell lines showed presence of hyperchromatic vesicular nucleus with 2 or 3 nucleoli. The cytoplasm showed presence of ribosomes, bundles of microfilaments and secretary vesicles. The cells were polygonal and attached to each other with tight junctions and desmosomes. Few microvilli were also present at the cell surface (Figure 7).

\section{Anchorage independent growth}

NIPBC-1 and NIPBC-2 when plated as single suspension on $0.3 \%$ agar, formed large colonies (40-100) after 2 weeks, MCF7 cell lines were used as positive control for this experiment which also formed large colonies on agar (Figure 8).

\section{Population doubling time}

Population doubling time of cell lines NIPBC-1 and NIPBC-2 cell lines were determined as described in materials and methods. The doubling time of NIPBC-1 cell line was found to be $33.25 \mathrm{hrs}$, while that of NIPBC-2 was 31.56 hrs (Figure 9). (a)

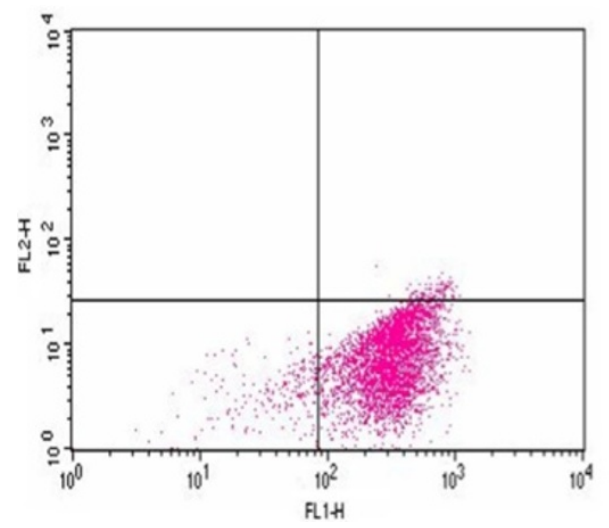

(b)

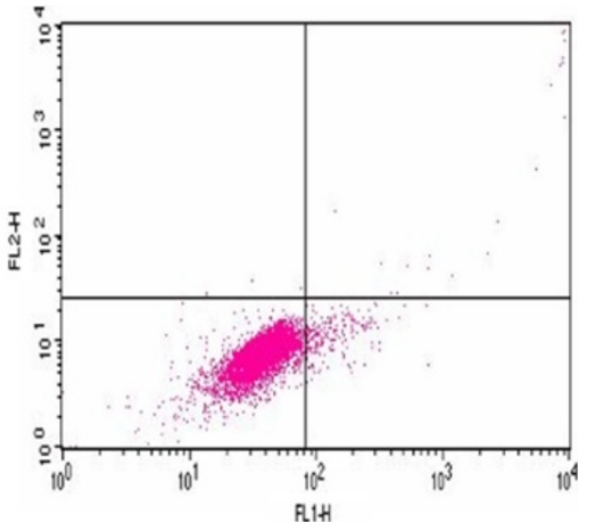

Figure 6 Expression of cell cycle markers by FACS in NIPBC-2 cell line. (a) P53 (91.80\%) (b) P21 (4.25\%). 

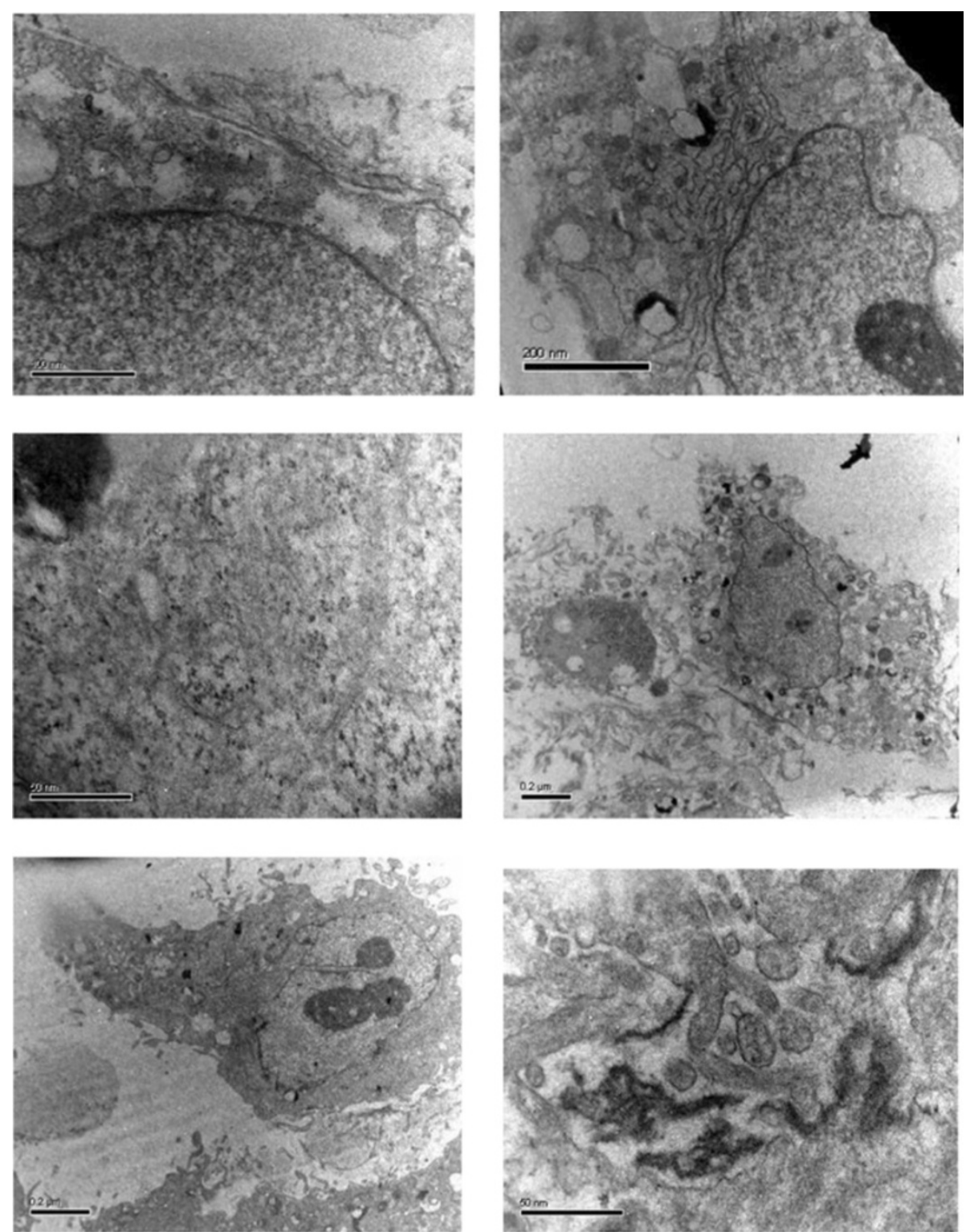

Figure 7 Electron micrographs of the established cell lines.

\section{Karyotype analysis}

Karyotype analysis of NIPBC-1 and NIPBC-2 cells has shown that both the cell lines possess aneuploidy. Chromosomes 7, 9, X and 11 showed deletions in various regions in both the cell lines. Cytogenetic analysis has shown multiple rearrangements. NIPBC-1 was near tetraploid with a modal number of 58 to 62 chromosomes, most of the chromosomes exhibited several translocations and marker chromosomes; rearrangements like $\mathrm{t}$ $(14: 15)$ (q12:q12) and $\mathrm{i}(17 \mathrm{q})$ were found commonly in these cells; Isochromosomes $17 \mathrm{q}$ was the most common aberration identified in NIPBC-1 (Figure 8). NIPBC-2 cell line was also found to be aneuploid with nearly tetraploid to pentaploid complement and the chromosomal numbers ranged from 107 to110 (Figures 10 and 11). No significant karyotype changes were found in the karyotypic analysis among the early and late passages of both the cell lines; indicating that both NIPBC-1 and NIPBC-2 are stable cell lines.

\section{DNA finger print/STR analysis}

STR profiling of standard STR markers [37] was done for both NIPBC-1 and NIPBC-2 cell lines established distinct profiles of both the cell lines. (Additional file 2: Table S1) Both the cell lines did not show any peak for the mouse marker MUS. The marker Amelogenin has 
(a)

(i)

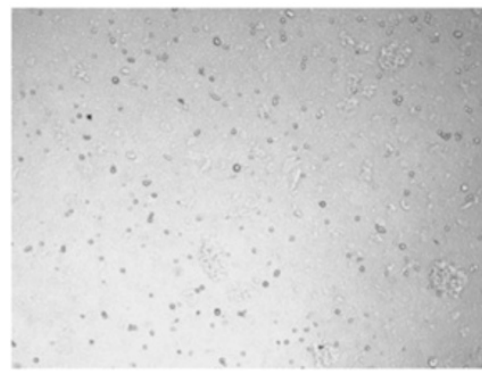

(iii)

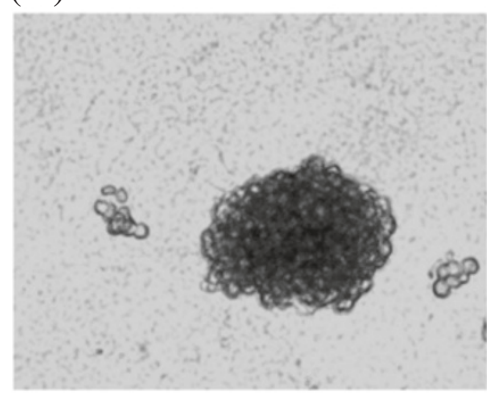

(b)

(i)

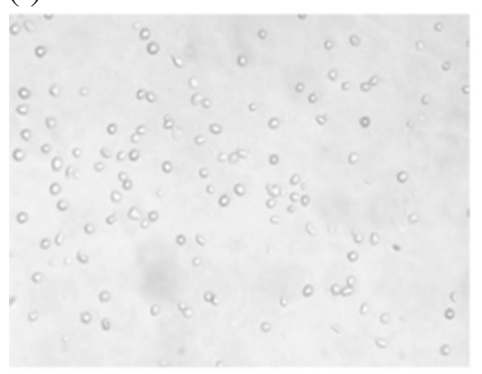

(ii)

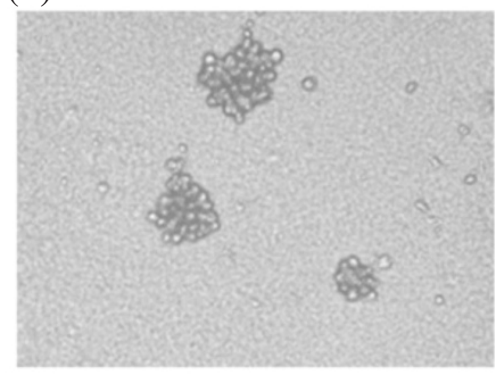

(ii)

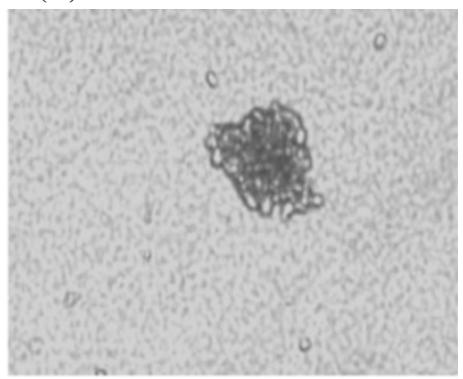

(iii)

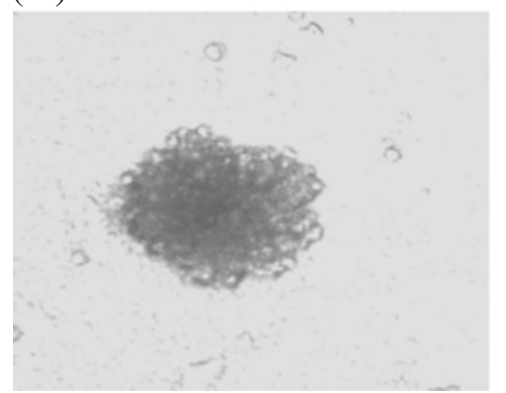

Figure 8 Representative pictures of colonies formed in anchorage independent growth by (a) NIPBC- 1 and (b) NIPBC- 2 cell lines at (i) day 1, (ii) day 7 and (iii) day 14 .

shown only a single peak with an allele size of 104, which shows that both the cell lines are from female origin with $\mathrm{XX}$ chromosomes. Further, this analysis established the fact that there is no cross contamination among the two cell lines.

\section{Invasion assay}

To examine the invasion capacity of the two cell lines established in the present study, we have carried out invasion assay on matrigel coated membrane inserts. We found invaded cells on the other side of the membrane 


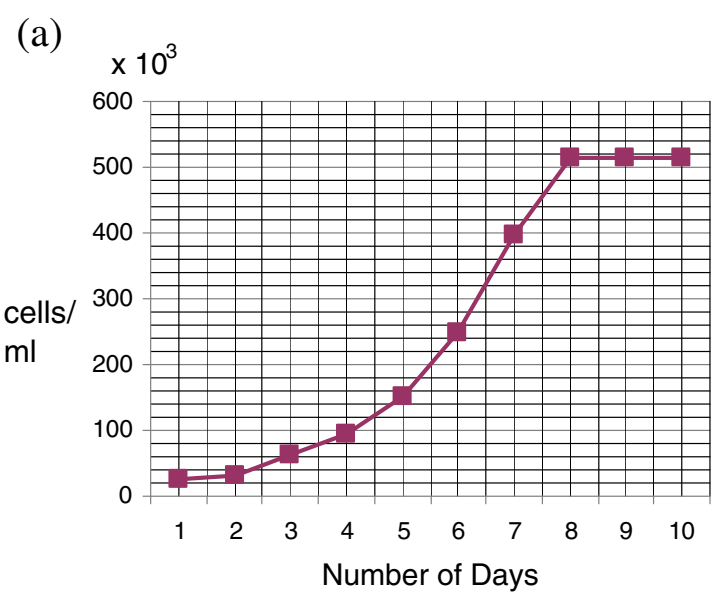

(b)

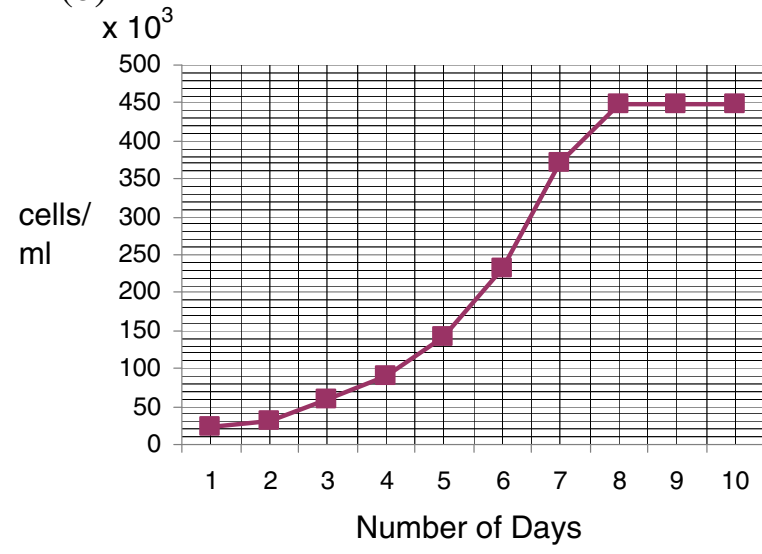

Figure 9 Population doubling time: cells were plated in 6-well plates at a plating density of $1 \times 105 \mathrm{~cm} 2$ in DMEM growth medium, supplemented with $10 \%$ FBS. Growth medium was renewed every 3 days. Cell counts were performed on the days indicated. Each point represents the mean of three different determinations made in triplicate. The population doubling times of the established cell lines (a) NIPBC-1 and (b) NIPBC-2 were calculated to be 33.25 hrs and 31.56 hrs respectively.

upon overnight incubation with chemo attractant (FBS). Breast cancer cell line MDA-MB231 was taken as positive control. The number of cells invading the matrigel matrix are counted in atleast 4 randomly choosen fields per well. The numbers of MDA-MB231, NIPBC-1 and NIPBC-2 cells that invaded through the basement membrane were $527 \pm 45.9020,409.3 \pm 32.3161,290.6 \pm 44.2417$ respectively (Figure 12a-c). The number of NIPBC-1 cells that invaded through the basement membrane was significantly higher than that of NIPBC-2 cell line $(p=0.0407)$ (Figure 12d).

\section{Test for mycoplasma contamination}

Various passages of both NIPBC-1 and NIPBC-2 cell lines were tested for the presence of mycoplasma by a
PCR based method using "Venor GeM Mycoplasma detection kit". Both the cell lines have been found to be free of mycoplasma contamination (Figure 13).

\section{BRCA gene status}

BRCA1 gene status in the two established cell lines was checked by automated sequencing, no mutation was detected in the coding regions. Further, we found four heterozygous polymorphisms in exon 11 of BRCA1 and two polymorphisms in exons 11, and 14 of BRCA2 gene in these cell lines (Figure 14) (Additional file 3: Table S2).

\section{TP53 mutational analysis}

No mutation was found in the coding regions of both NIPBC-1 and NIPBC-2 cell lines.

NIPBC-2 cell line has heterozygous C/G, g.417 C>G (NM_000546.5), at codon72of exon 4, resulting in p. P72R (Pro/Arg allele); While, NIPBC-1 has homozygous Pro/Pro allele (no change), at codon 72 (Figure 15) (Additional file 4: Table S3).

\section{Expression of breast cancer stem cells by flow cytometry}

To obtain breast CSCs, we have stained and sorted both NIPBC-1 and NIPBC-2 cell lines using antibodies against CD44 and $\mathrm{CD} 24$ cell surface markers taking MCF7 breast cancer cell line as positive control. Although we could detect $0.2 \%$ and $0.1 \%$ of $\mathrm{CD}_{4} 4^{+} / \mathrm{CD} 24^{-}$ breast cancer stem cells in NIPBC-1 and NIPBC-2 cell lines respectively (Figure 16); expression of ALDHpositive BCSCs was not found (data not shown).

\section{Discussion}

We have established two triple negative breast cancer cell lines NIPBC-1 and NIPBC-2 from primary tumors of two young breast cancer patients ( 39 and 38 yrs old) both showing nonbasal origin. In India premenopausal patients constitute about $50 \%$ of all patients. Early-onset breast cancer may, in part, be biologically different from breast cancer patients in older patients [38]. Family history contributes to only $20 \%$ of the early onset cases whereas factors responsible for the rest of the breast cancer cases in young women are not known [39]. Difference in clinical behavior and molecular profile of early onset breast cancer suggest the need for understanding the risk factors and molecular mechanisms involved in development of breast cancer in young women. There are few breast cancer cell lines available $(<20 \%)$ from patients $<40$ years of age. The two cell lines established in the present study NIPBC-1 and NIPBC-2 were derived from breast cancer patients with the age 39 years and 38 years respectively, and represent breast cancers that occur at early age; hence may serve as in vitro models to study the early onset breast cancers in Indian women. The success rate of establishing cell lines in present 
(a)

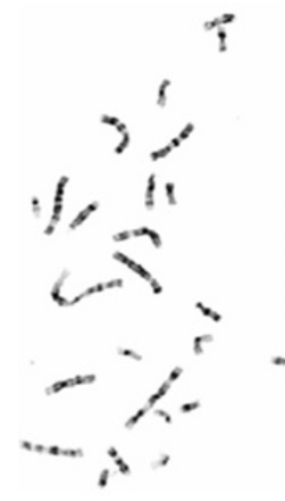

(c)

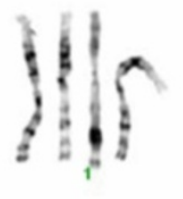

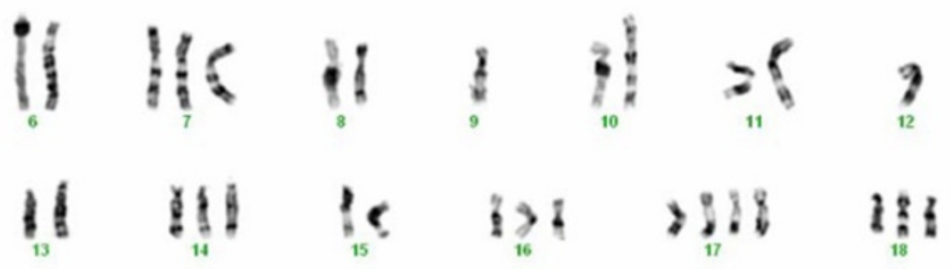

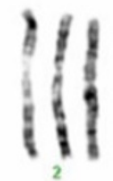

(b)

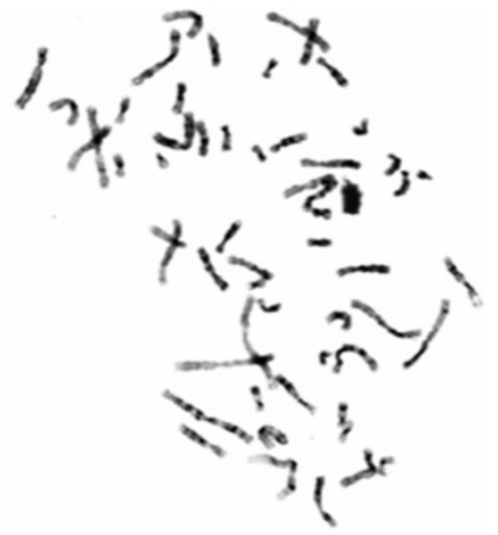


(a)

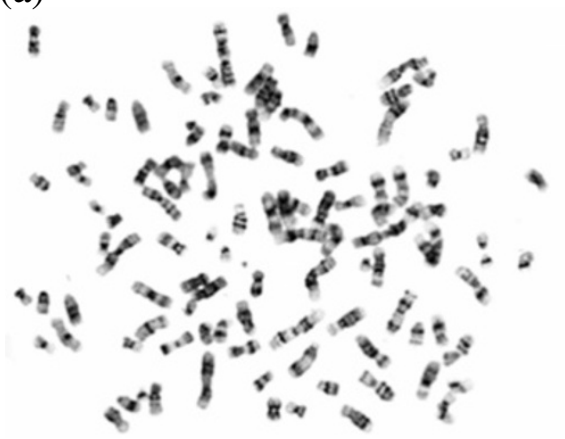

(b)

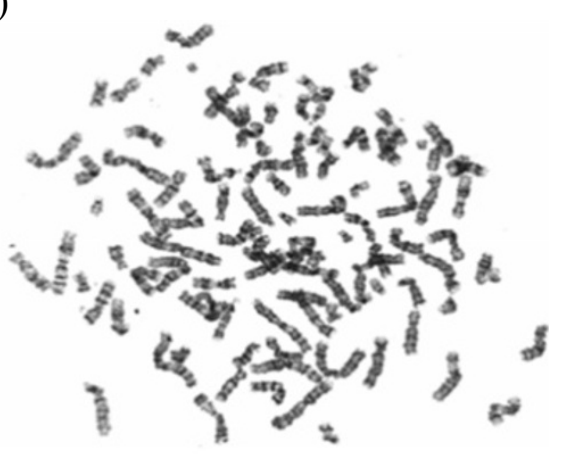

(c)

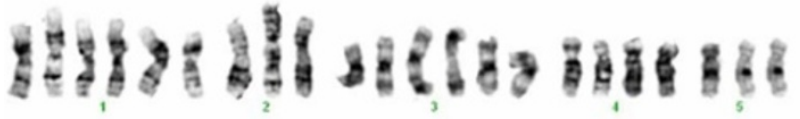

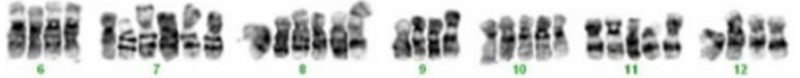

QA 4 ละ

8,888885000000000008 .

8 ह

(d)

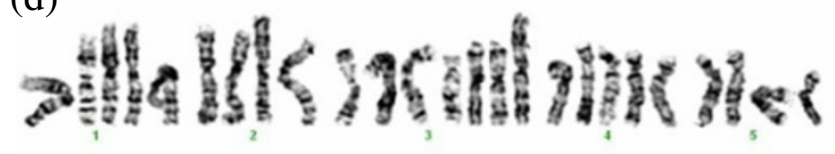

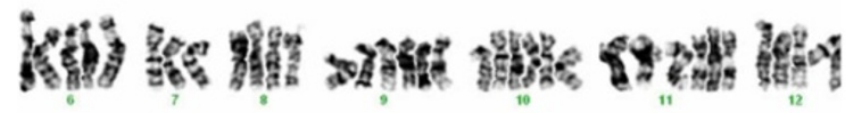

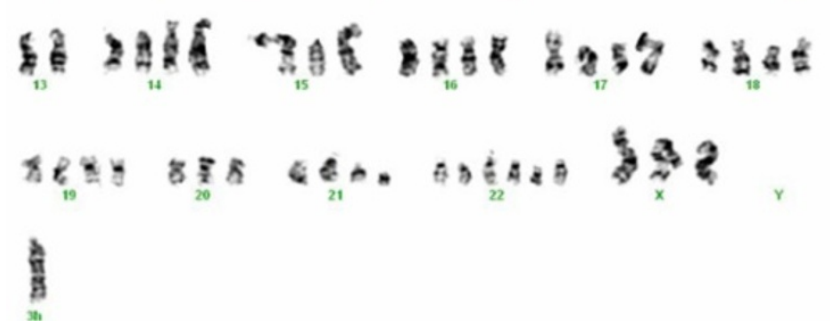

Figure 11 Representative metaphases (a, b) of NIPBC-2 cells, at passages 15 and 52, with trypsin-giemsa banding. Karyotypes (c, d) of the above metaphases showing near tetraploidy with a modal number of 58 to 62 chromosomes.

study is $4.5 \%$ ie., 2 cell lines using 44 primary tumors which is comparable to other studies in breast cancer where also low success rate had been reported [40]. The epithelial origin of both the cell lines, NIPBC-1 and NIPBC-2 has been confirmed by electron microscopic examination and immunofluorescence. Both NIPBC-1 and NIPBC-2 cells are negative for cytokeratin 5/6 and positive for EMA, demonstrating their non-basal epithelial nature. NIPBC-1 cells showed over expression of MUC1 cells, suggesting their transformed nature [41,42], further it has shown punctate vimentin positivity suggesting metaplastic behavior of these cells, which is 

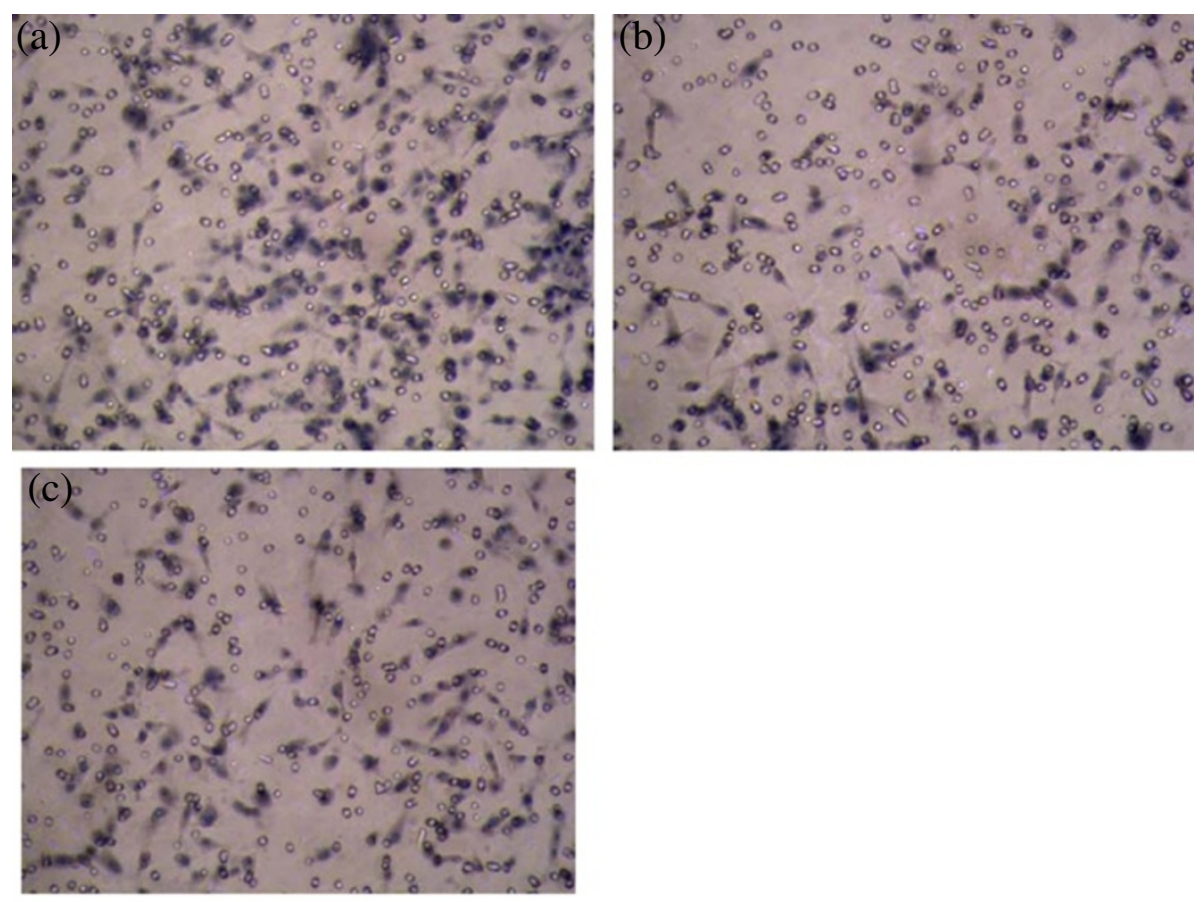

(d)

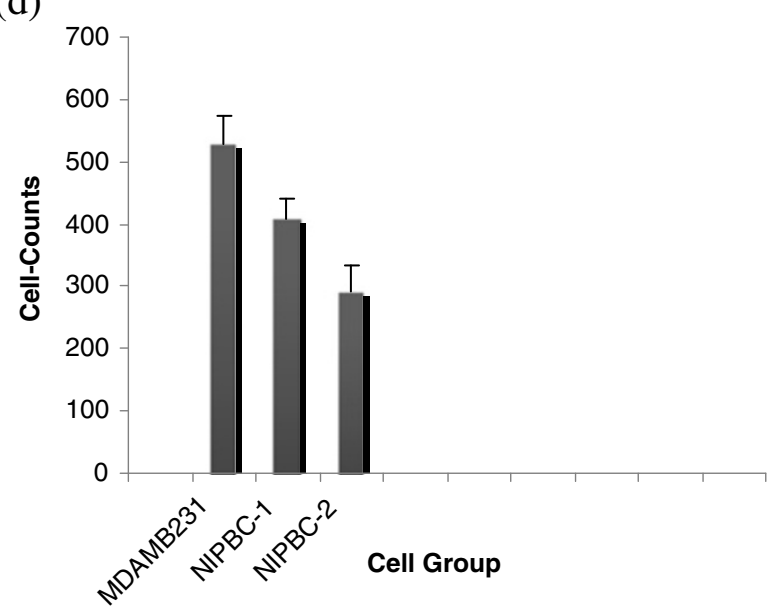

Figure 12 Invasion assay of NIPBC-1 and NIPBC-2 cell lines. Representative pictures of (a) MDA MB 231 (positive control), (b) NIPBC-1 and (c) NIPBC-2 cells invaded through Matrigel. (d) Cell number quantification of invasion.

corroborating with their spindle shape. Vimentin has been previously linked to the metaplastic potential of cancer cells as its increased expression has been demonstrated to be a marker of epithelial mesenchymal transition (EMT). Also Willipinski-Stapelfeldt et al., [43] stained more than 2500 primary breast tumors and demonstrated that approximately $35 \%$ of hormone receptor negative tumors expressed vimentin but only $7 \%$ of hormone receptor positive tumors expressed vimentin. Also Connie L. Sommers et al., [44] reported that vimentin was expressed by more than one-half of the hormone- independent breast carcinoma cell lines tested but not by the hormone-dependent cell lines. Moreover it is a well established fact that most eukaryotic cells start expressing vimentin when brought into tissue culture $[45,46]$.

Vimentin which was originally identified as an intermediate filament protein present only as an intracellular component has been detected recently on the surface of cancer cells but not on healthy cells in a punctate distribution pattern. Nicole F. Steinmetz et al., $[47,48]$ have demonstrated that surface vimentin can be used as a common marker to detect highly metastatic cancer cells. 


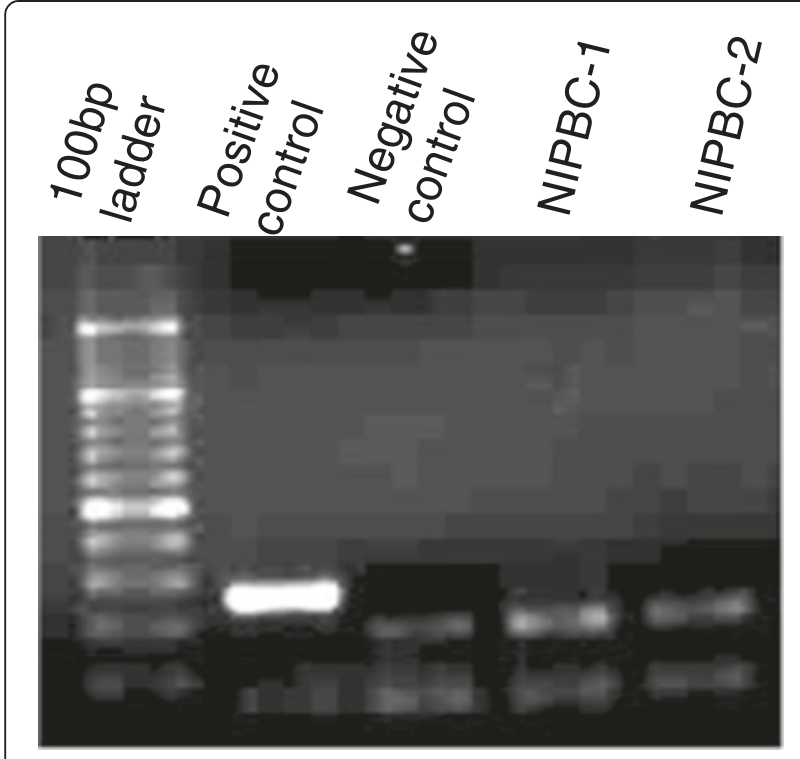

Figure 13 Test for mycoplasma contamination in NIPBC-1 and NIPBC-2 cell lines.

They have also examined the coexpression of surface vimentin with the CD44 and CD133 stem- or progenitor cell marker proteins and demonstrated that Cowpea mosaic virus (CPMV) nanoparticles can bind to the surface domains of vimentin thereby facilitating drug targeting in prostate cancer. NIPBC-1 cell line which expresses punctate surface vimentin can be used as a model for creating nanoparticle- or antibody- cancer therapeutic agents capable of targeting vimentin in combination with other surface markers to prevent cancer metastasis as well as kill cancer stem cells. Also it can be used as a model to detect highly metastatic cancer cells.

The ultra structural features confirming epithelial origin of both the cell lines include presence of bundles of microfilaments, secretary vesicles, tight junctions, desmosomes, and granular cytoplasm with numerous ribosomes. Both NIPBC-1 and NIPBC- 2 cell lines are negative for estrogen receptor (ER), progesterone receptor (PR) and HER2/neu, and hence represent triple negative breast cancers (TNBC), which are considered to be aggressive tumors having higher histological grade, worse prognosis and occur mostly in younger women [49-51]. Most of the triple negative tumors are of basal type [51], however, the two cell lines we have established are triple negative but are of non-basal origin which makes them unique. It has been observed that Indian breast cancer patients have a higher tendency to have triple negative tumors as compared to western patients. Incidence of triple negative breast cancer in Indian breast cancer patients has been reported between 19.9 - to $24.8 \%$ compared to $15 \%$ in the SEER, and there is significant correlation of TN Breast cancer with younger age $(<35$ years, $\mathrm{P}<0.003)$ and high level of p53 mutations $(\mathrm{P}<0.001)$. The younger the age of the patient, the greater are the chances of the cancer being ER negative, with $63.5 \%$ of patients under 50 years of age having ER negative tumors, and 33\% of patients under 50 years of age having TNBC [52]. Khokhar et al., [53] reported that Estrogen (ER) and progesterone receptors (PR) are found positive in only $20-45 \%$ of Indian patients. ER-positive rates were reported to be lower in Indian patients than those in western countries. Rao et al., [54] reported that 33\% of triple negative phenotype breast carcinomas show expression of basal markers (CK5/6 and/or over-expression of EGFR) and that "Triple negative" status cannot be used as a surrogate for "basal marker expression".

NIPBC-1 and NIPBC-2 both formed large colonies on soft agar confirming the transformed nature of both the two established cell lines since the ability to form anchorage independent colonies is related to transformed nature of the cells [55]. Further, these cell lines showed positivity for invasion on matrigel confirming their malignant nature.

Both NIPBC-1 and NIPBC-2 cell lines have shown aneuploidy upon karyotyping, which is a feature of neoplastic cells, supporting their neoplastic origin. Further they exhibited several translocations and rearrangements pointing towards their neoplastic nature. The karyotypes of both NIPBC-1 and NIPBC-2 cell lines exhibit isochromosome $17 \mathrm{q}$. The isochromosome 17 , $\mathrm{i}(17 \mathrm{q})$ is a relatively common karyotype abnormality, that results in loss of the short arm (17p) and duplication of the long arm (17q) leading to a single copy of $17 p$ and three copies of $17 q$, that has been observed in solid tumors such as medulloblastoma, gastric cancer, bladder and breast cancers, associated with tumor development and progression [56,57]. This is linked to poor survival outcome due to the complex conditions of two important prognostic determinants: loss of tumor suppressors (chromosome 17p) and high expression of oncogenes c-myc (MYCC) or N-myc (MYCN) [58]. Chromosomal gains/ loses among the early and late passages were observed. The karyotypes of the late passages of cell lines showed less variability of numerical aberrations apparently due to clonal adaptation to in vitro conditions. However we would like to point out that cell lines are autonomous dynamic systems with an unlimited lifespan in culture. Numerous studies [59] have reported changes of cell line Karyotype during prolonged cultivation due to changes of culture conditions. It was also demonstrated that even in characterized cell lines, because these cells are continually evolving, there is heterogeneity in karyotypes within the same culture $[60,61]$.

Mutations in tumor suppressor genes BRCA1/2 and P53 genes are significant contributing factors for breast 

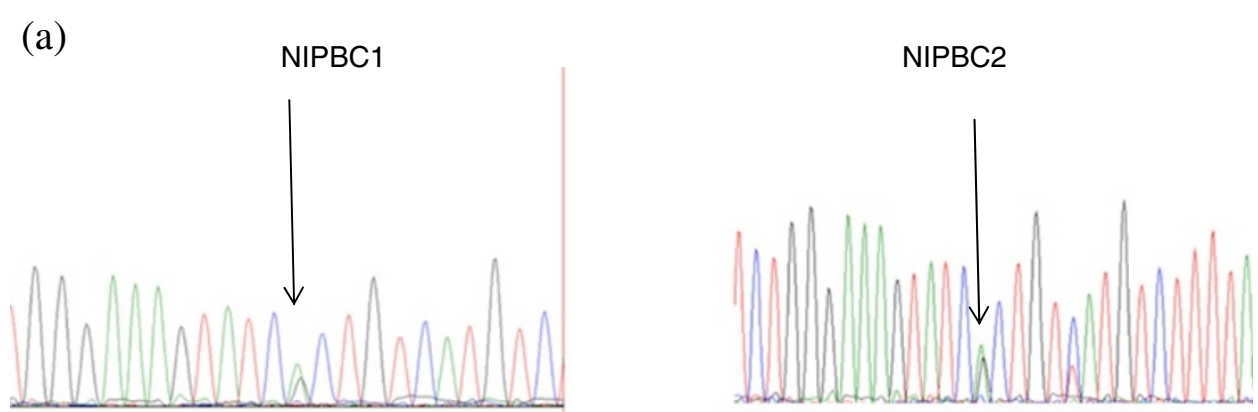

(b)

NIPBC1

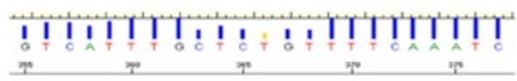

(c)
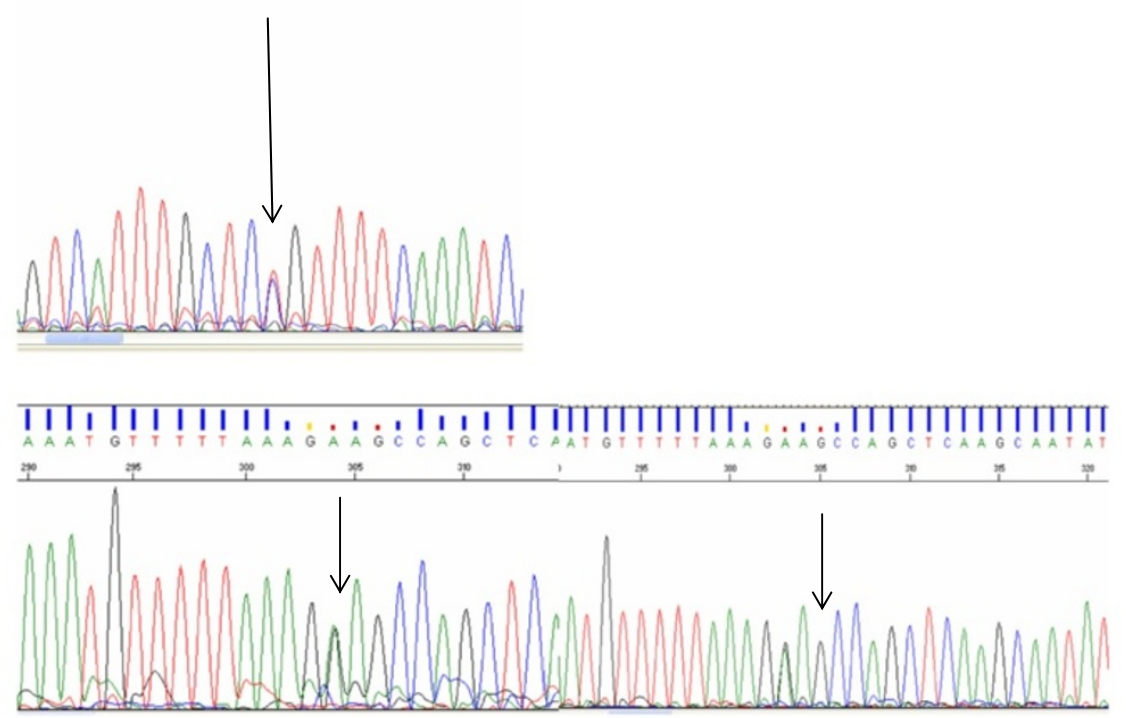

(d)

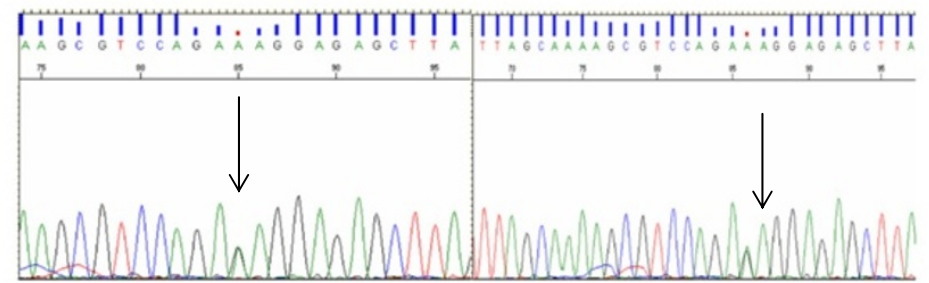

(e)

\footnotetext{
Figure 14 (See legend on next page.)
} 
(See figure on previous page.)

Figure 14 Sequence variations found in BRCA1 and BRCA2 genes in NIPBC-1 and NIPBC-2. (a) BRCA1 exon 11 polymorphism, g. 2201 C > T heterozygous allele (Gen Bank Id U14680.1) (b) BRCA1Exon 11- g.2731 C> T heterozygous allele (Gen Bank Id U14680.1) (c) BRCA1 exon11-g.3232 A > G heterozygous in both the cell lines (Gen Bank Id U14680.1) (d) BRCA1 Exon 11- g.3667 G>A heterozygous in in both cell lines (Gen Bank Id U14680.1) (e) BRCA2 exon11- g. 3199 A > G heterozygous in both the cell lines (Gen Bank Id U14680.1).

carcinogenesis; hence we have screened these cell lines for mutations/ polymorphisms in these genes. Genetic mutation or allelic polymorphisms in p53 gene are the most common genetic changes associated with much cancer susceptibility in human cancers, such as cervical cancer, breast cancer, lung and colorectal cancer [62]. Although no mutation in coding regions of p53 gene has been noticed in both NIPBC-1 and NIPBC-2 cell lines, however a $\mathrm{C} / \mathrm{G}$ polymorphism, g.417 C $>\mathrm{G}$, at codon 72 has been found in NIPBC-2 cell line leading to arginine (A72) being replaced by proline (P72). Numerous polymorphisms in the wild-type p53 have been reported in both the coding and noncoding regions [63]. Of the five polymorphisms described in the coding region, polymorphisms in codon 47 and 72 in exon 4 are functionally well characterized. More common of the two, codon 72 polymorphism is a single-base substitution of cytosine for guanine, leading to arginine (A72) being replaced by proline (P72) [63], and this has been reported to be associated with the risk of several cancers [64-68]. The distribution of the three genotypes (Arg/Arg, Arg/Pro and Pro/Pro) depends largely on the ethnic composition of the studied population [69]. Even though, the p53Arg72 and p53Pro 72 proteins do not differ in their ability to bind to DNA, they bind to components of different transcriptional machinery, influencing differential susceptibility to cancer [70,71]. The p53Arg72 protein induces apoptosis faster and suppresses transformation more efficiently than the p53Pro72 protein [62,72]. The p53 Arg72Arg polymorphism may be used as a stratification marker in screening individuals at a high risk of breast cancer $[73,74]$.

Mutations in BRCA1 and BRCA2 genes are associated with predisposition to breast cancer; hence we have screened both the cell lines for mutations/ polymorphisms in these genes. Several polymorphisms were observed, among polymorphisms in BRCA1 exon 11, g.2201 C > T is a frequent polymorphism reported in US [75,76], and European population [75]; while polymorphism at nucleotide g.3667 G > A had earlier been reported in north Indian population [22]. The other polymorphisms g2731 C > T, g.3232 A > G and g.3667 G>A in exon 11 of BRCA1 have been reported in Korean population [32,77]. The BRCA2 Exon14 g.7470 A > G polymorphism found in both the cell lines had also been reported earlier in north Indian population [32]. The exon 11 g.3199 A > G polymorphism in BRCA2 was reported by WECARE Study Collaborative Group in US and European patients and is also reported in Chinese population $[75,78]$.

CSCs have been isolated from many solid tumors, including breast [36,79], pancreatic [80,81], brain [82,83], colon [84-86], liver [87], head/neck [88], ovarian [89,90], and melanoma [91,92]. CSCs were first isolated and characterized by Al-Haji et al. using the cell surface marker $\mathrm{CD} 44^{+} / \mathrm{CD} 24^{-/ \text {low }} / \mathrm{Lin}$ - and recapitulated the

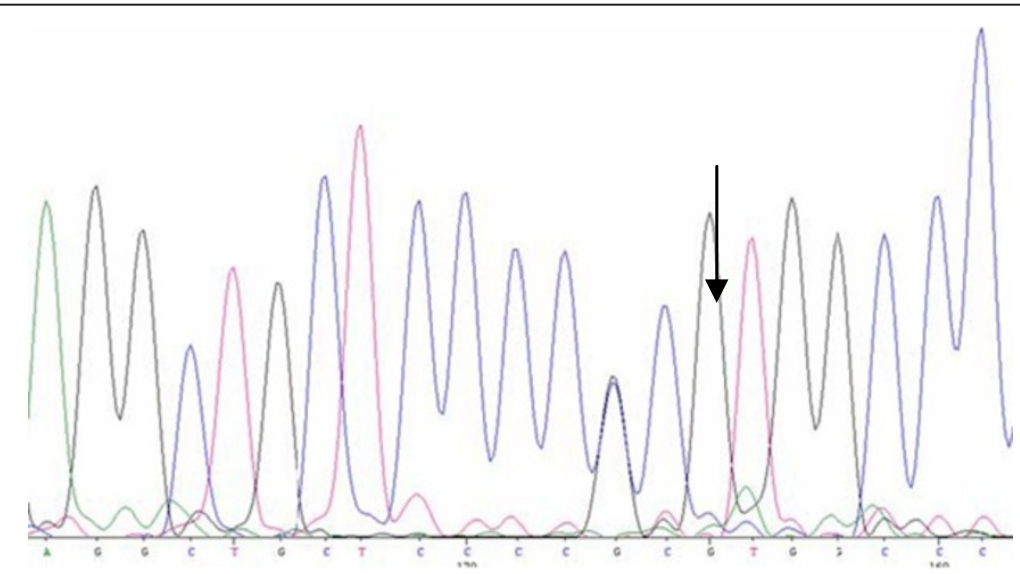

Figure 15 TP53 mutational analysis. NIPBC-2 cell line has heterozygous C/G, g.417 C> G (NM_000546.5), at codon72 of exon 4, resulting in p. P72R (Pro/Arg allele). 


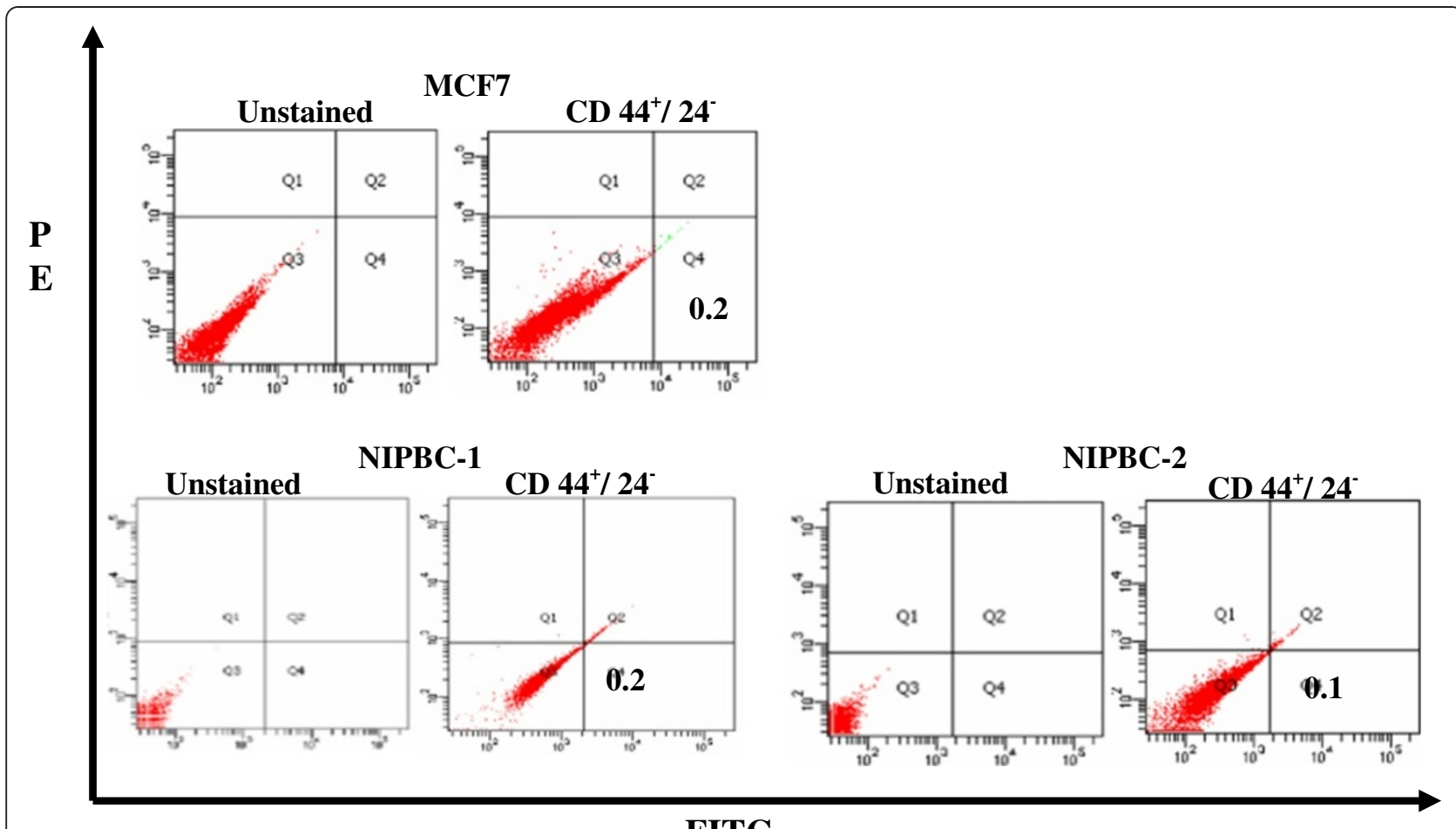

FITC

Figure 16 Flow cytometry sorting of MCF7, NIPBC-1 and NIPBC-2 cells using CD44 and CD24 markers. Cells were analyzed by fluorescence-activated cell sorting (FACS) using anti-CD44 and anti-CD24 antibodies.

heterogeneity of the original tumor by injecting them into nude mice [36]. Both NIPBC-1 and NIPBC-2 cell lines showed the presence of $0.2 \%$ and $0.1 \%$ of $\mathrm{CD} 44^{+} / \mathrm{CD} 24^{-}$ breast cancer stem cells respectively which is relatively similar to the commercially available breast cancer cell line. When plated in serum free, non-adherent conditions as described earlier [33], both NIPBC-1 and NIPBC-2 cell lines formed mammospheres (Figure 17) and could be further passaged for three generations.

Molecular analysis of the cell lines was done to identify unique properties of the cell lines. Short tandem repeat (STR) profiling was done to ensure the integrity of human cell lines. The STR profile of NIPBC-1 and 2 found to be unique and do not match among themselves and also with other cell lines in the laboratory that are being used, which shows these two cell lines are novel. Although a number of normal and breast cancer cell lines established from western patients are available, there is a paucity of cell lines established from Indian breast cancer patients. So far only two breast cancer cell lines have been established from late onset breast cancer patients (>60 years) using primary tumors [24], hence the two cell lines we have established in the present study are unique with respect to the ethnicity also as these are the first breast cancer cell lines to be established from Indian continent representing early onset breast cancers. In conclusion, in the present study we have established two novel triple negative breast cancer cell lines, NIPBC-1 and NIPBC-2 from primary tumors of two early onset breast cancers ( $<40$ years), which may serve as valuable in vitro models to study breast tumorigenesis in young breast cancer patients and identification of unique therapeutic targets.

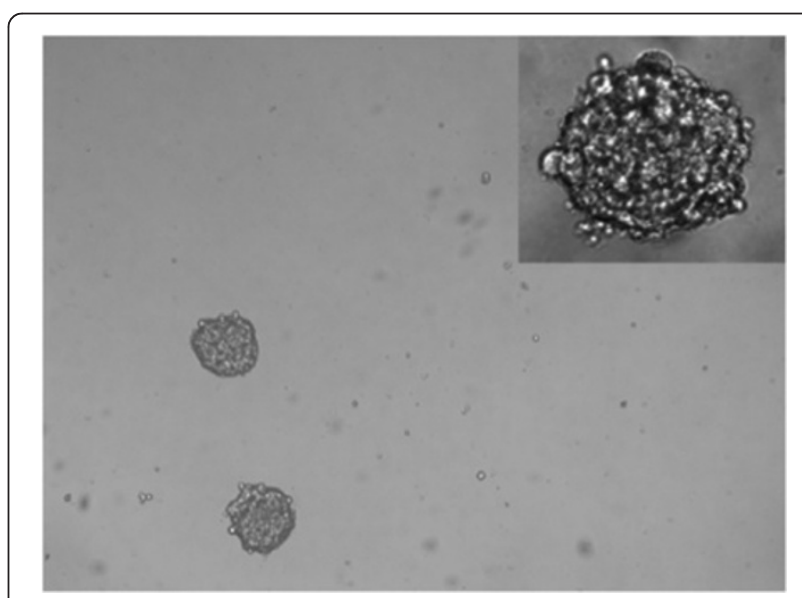

Figure 17 Representative pictures of mammospheres formed by NIPBC1 \& NIPBC-2 cell lines. (Magnification- 40x, inset mag- 100x). 


\section{Additional files}

Additional file 1: Figure S1. Expression of cell cycle marker Ki67 by FACS in MCF7, NIPBC-1 and NIPBC-2 cell lines along with their isotype controls. (a) MCF7 (b) NIPBC-1 (73.01\%) (c) NIPBC-2 (94.11\%).

Additional file 2: Table S1. STR profiling of NIPBC-1 and NIPBC-2 cell lines.

Additional file 3: Table S2. Sequence variations found in BRCA1 and BRCA2 genes in NIPBC-1 and NIPBC-2.

Additional file 4: Table S3. List of primers used for p53 sequencing

\section{Competing interests}

The authors declare that they have no competing interests.

\section{Authors' contributions}

Performed the experiments: SLP. Analyzed the data: SLP and SS. Provided breast tumor tissue for establishment of breast cancer cell lines: NKS, CC, MRS and DB. Helped in purification of cell lines: BSA; Maintainence of cell lines: BSA, SLP; Helped in Karyotype analysis and mycoplasma detection: MK, RD, ML. Helped in P53 and STR analysis: BSA, ML, AS, SM and SSimon. Overall supervision of the project: SS. Contributed reagents/materials/ analysis tools: SS. Wrote the manuscript: SLP and SS. All authors read and approved the final manuscript

\section{Acknowledgements}

This study was funded by Indian Council of Medical Research (ICMR), Ansari Nagar, New Delhi, we are grateful to ICMR for funding the project. SLP, AS and SM would like to thank ICMR and ML wants to thank CSIR for their research fellowship.

\section{Author details}

'National Institute of Pathology (ICMR), Safdarjung Hospital Campus, New Delhi 110029, India. ${ }^{2}$ Rajiv Gandhi Cancer Institute and Research Centre, Rohini, New Delhi, India. ${ }^{3}$ Lab for Molecular Reproduction and Genetics, Anatomy department, All India Institute of medical Sciences, New Delhi, India. ${ }^{4}$ Department of Surgery, Safdarjung Hospital Campus, New Delhi 110029, India.

Received: 3 October 2013 Accepted: 1 February 2014

Published: 5 February 2014

\section{References}

1. Jemal A, Bray F, Center MM, Ferlay J, Ward E, Forman D: Global cancer statistics. CA Cancer J Clin 2011, 61(2):69-90.

2. National cancer registry programme. http://www.icmr.nic.in/ncrp/ first report_2003-04/Starting\%20Pages.pdf.

3. Catalani S: Lancet-Oncology-a summary of the review on IARC carcinogens: metallic elements, dusts and fibers. G Ital Med Lav Ergon 2009, 31(2):182-183.

4. Assi HA, Khoury KE, Dbouk H, Khalil LE, Mouhieddine TH, El Saghir NS: Epidemiology and prognosis of breast cancer in young women. $J$ Thorac Dis 2013, 5(1):S2-S8.

5. Winchester DP, Osteen RT, Menck HR: The National Cancer Data Base report on breast carcinoma characteristics and outcome in relation to age. Cancer 1996, 78(8):1838-1843.

6. Nixon AJ, Neuberg D, Hayes DF, Gelman R, Connolly JL, Schnitt S, Abner A, Recht A, Vicini F, Harris JR: Relationship of patient age to pathologic features of the tumor and prognosis for patients with stage I or II breast cancer. J Clin Oncol 1994, 12(5):888-894.

7. Host H, Lund E: Age as a prognostic factor in breast cancer. Cancer 1986, 57(11):2217-2221.

8. Adami HO, Malker B, Holmberg L, Persson I, Stone B: The relation between survival and age at diagnosis in breast cancer. N Engl J Med 1986, 315(9):559-563.

9. Bonnier P, Romain S, Charpin C, Lejeune C, Tubiana N, Martin PM, Piana L: Age as a prognostic factor in breast cancer: relationship to pathologic and biologic features. Int J Cancer Suppl 1995, 62(2):138-144.

10. Dobrynin YV: Establishment and characteristics of cell strains from some epithelial tumors of human origin. J Natl Cancer Inst 1963, 31:1173-1195.
11. Soule HD, Vazguez J, Long A, Albert S, Brennan M: A human cell line from a pleural effusion derived from a breast carcinoma. J Natl Cancer Inst 1973, 51(5):1409-1416.

12. Engel LW, Young NA, Tralka TS, Lippman ME, O'Brien SJ, Joyce MJ: Establishment and characterization of three new continuous cell lines derived from human breast carcinomas. Cancer Res 1978, 38(10):3352-3364.

13. Siwek B, Larsimont D, Lacroix M, Body JJ: Establishment and characterization of three new breast-cancer cell lines. Int J Cancer 1998 76(5):677-683

14. Zoli W, Roncuzzi L, Zini N, Lenzi L, Gruppioni R, Barzanti F, Sensi A, Amadori D, Gasperi-Campani A: Establishment and characterization of two new cell lines derived from human metastatic breast carcinomas. Breast Cancer Res Treat 1997, 43(2):141-151.

15. Band V, Zajchowski D, Stenman G, Morton CC, Kulesa V, Connolly J, Sager R: A newly established metastatic breast tumor cell line with integrated amplified copies of ERBB2 and double minute chromosomes. Genes Chromosomes Cancer 1989, 1(1):48-58.

16. Mahacek ML, Beer DG, Frank TS, Ethier SP: Finite proliferative lifespan in vitro of a human breast cancer cell strain isolated from a metastatic lymph node. Breast Cancer Res Treat 1993, 28(3):267-276.

17. Ethier SP, Mahacek ML, Gullick WJ, Frank TS, Weber BL: Differential isolation of normal luminal mammary epithelial cells and breast cancer cells from primary and metastatic sites using selective media. Cancer Res 1993, 53(3):627-635

18. Cailleau R, Young R, Olive $M$, Reeves WJ Jr: Breast tumor cell lines from pleural effusions. J Natl Cancer Inst 1974, 53(3):661-674.

19. Wang CS, Goulet F, Lavoie J, Drouin R, Auger F, Champetier S, Germain L, Tetu B: Establishment and characterization of a new cell line derived from a human primary breast carcinoma. Cancer Genet Cytogenet 2000, 120(1):58-72.

20. Vandewalle B, Collyn d'Hooghe M, Savary JB, Vilain MO, Peyrat JP, Deminatti $M$, Delobelle-Deroide A, Lefebvre J: Establishment and characterization of a new cell line (VHB-1) derived from a primary breast carcinoma. $J$ Cancer Res Clin Oncol 1987, 113(6):550-558.

21. Minafra S, Morello V, Glorioso F, La Fiura AM, Tomasino RM, Feo S, Mclntosh D, Woolley DE: A new cell line (8701-BC) from primary ductal infiltrating carcinoma of human breast. Br J Cancer 1989, 60(2):185-192.

22. Meltzer $P$, Leibovitz A, Dalton W, Villar H, Kute T, Davis J, Nagle R, Trent J: Establishment of two new cell lines derived from human breast carcinomas with HER-2/neu amplification. Br J Cancer 1991, 63(5):727-735.

23. Nordquist RE, Ishmael DR, Lovig CA, Hyder DM, Hoge AF: The tissue culture and morphology of human breast tumor cell line BOT-2. Cancer Res 1975 35(11 Pt 1):3100-3105.

24. Raju Bagadi SA, Kaur J, Ralhan R: Establishment and characterisation of two novel breast cancer cell lines. Cell Biol Int 2008, 32(1):55-65.

25. Tralka TS, Costa J, Rabson A: Electron microscopic study of Herpesvirus saimiri. Virology 1977, 80(1):158-165.

26. Courdi A, Gioanni J, Lalanne CM, Fischel JL, Schneider M, Ettore F, Lambert JC: Establishment, characterization, and response to cytotoxic and radiation treatment of three human melanoma cell lines. In Vitro 1983, 19(6):453-461.

27. Wang HC, Fedoroff S: Banding in human chromosomes treated with trypsin. Nat New Biol 1972, 235(54):52-54

28. Mosmann T: Rapid colorimetric assay for cellular growth and survival: application to proliferation and cytotoxicity assays. $J$ Immunol Methods 1983, 65(1-2):55-63.

29. Denizot F, Lang R: Rapid colorimetric assay for cell growth and survival. Modifications to the tetrazolium dye procedure giving improved sensitivity and reliability. J Immunol Methods 1986, 89(2):271-277.

30. Garcia CC, Candurra NA, Damonte EB: Mode of inactivation of arenaviruses by disulfide-based compounds. Antiviral Res 2002, 55(3):437-446.

31. Bernhard D, Schwaiger W, Crazzolara R, Tinhofer I, Kofler R, Csordas A: Enhanced MTT-reducing activity under growth inhibition by resveratrol in CEM-C7H2 lymphocytic leukemia cells. Cancer Lett 2003, 195(2):193-199.

32. Saxena S, Chakraborty A, Kaushal M, Kotwal S, Bhatanager D, Mohil RS, Chintamani C, Aggarwal AK, Sharma VK, Sharma PC, Lenoir G, Goldgar DE, Szabo Cl: Contribution of germline BRCA1 and BRCA2 sequence alterations to breast cancer in Northern India. BMC Med Genet 2006, 7:75.

33. Pandrangi SL, Chikati R, Chauhan PS, Kumar CS, Banarji A, Saxena S: Effects of ellipticine on ALDH1A1-expressing breast cancer stem cells-an in vitro and in silico study. Tumour Biol 2013, 35:723-737. 
34. Corti S, Locatelli F, Papadimitriou D, Donadoni C, Salani S, Del Bo R, Strazzer S, Bresolin N, Comi GP: Identification of a primitive brain-derived neural stem cell population based on aldehyde dehydrogenase activity. Stem Cells 2006, 24(4):975-985.

35. Li Y, Zhang T, Korkaya H, Liu S, Lee HF, Newman B, Yu Y, Clouthier SG, Schwartz SJ, Wicha MS, Sun D: Sulforaphane, a dietary component of broccoli/broccoli sprouts, inhibits breast cancer stem cells. Clin Cancer Res 2010, 16(9):2580-2590.

36. Al-Hajj M, Wicha MS, Benito-Hernandez A, Morrison SJ, Clarke MF: Prospective identification of tumorigenic breast cancer cells. Proc Natl Acad Sci U S A 2003, 100(7):3983-3988

37. Mann B, Gelos M, Siedow A, Hanski ML, Gratchev A, Ilyas M, Bodmer WF, Moyer MP, Riecken EO, Buhr HJ, Hanski C: Target genes of beta-catenin-T cell-factor/lymphoid-enhancer-factor signaling in human colorectal carcinomas. Proc Natl Acad Sci U S A 1999, 96(4):1603-1608.

38. Walker RA, Lees $E$, Webb MB, Dearing SJ: Breast carcinomas occurring in young women (< 35 years) are different. British journal of cancer 1996, 74(11):1796-1800.

39. Saxena S, Rekhi B, Bansal A, Bagga A, Chintamani, Murthy NS: Clinicomorphological patterns of breast cancer including family history in a New Delhi hospital, India-a cross-sectional study. World J Surg Oncol [electronic resource] 2005, 3:67.

40. Gazdar AF, Kurvari V, Virmani A, Gollahon L, Sakaguchi M, Westerfield M, Kodagoda D, Stasny V, Cunningham HT, Wistuba II, Tomlison G, Tonk V, Ashfaq R, Leitch AM, Minna JD, Shay JW: Characterization of paired tumor and non-tumor cell lines established from patients with breast cancer. Int J Cancer 1998, 78(6):766-774.

41. Singh R, Bandyopadhyay D: MUC1: a target molecule for cancer therapy. Cancer Biol Ther 2007, 6(4):481-486.

42. Yang $E, H u$ XF, Xing PX: Advances of MUC1 as a target for breast cancer immunotherapy. Histol Histopathol 2007, 22(8):905-922.

43. Willipinski-Stapelfeldt B, Riethdorf S, Assmann V, Woelfle U, Rau T, Sauter G, Heukeshoven J, Pantel K: Changes in cytoskeletal protein composition indicative of an epithelial-mesenchymal transition in human micrometastatic and primary breast carcinoma cells. Clin Cancer Res 2005, 11(22):8006-8014

44. Sommers CL, Walker-Jones D, Heckford SE, Worland P, Valverius E, Clark R, McCormick F, Stampfer M, Abularach S, Gelmann EP: Vimentin rather than keratin expression in some hormone-independent breast cancer cell lines and in oncogene-transformed mammary epithelial cells. Cancer Res 1989, 49(15):4258-4263.

45. Franke WW, Grund C, Kuhn C, Jackson BW, IIImensee K: Formation of cytoskeletal elements during mouse embryogenesis. III. Primary mesenchymal cells and the first appearance of vimentin filaments. Differentiation 1982, 23(1):43-59.

46. Pieper FR, Van de Klundert FA, Raats JM, Henderik JB, Schaart G, Ramaekers FC, Bloemendal H: Regulation of vimentin expression in cultured epithelial cells. Eur J Biochem 1992, 210(2):509-519.

47. Steinmetz NF, Cho CF, Ablack A, Lewis JD, Manchester M: Cowpea mosaic virus nanoparticles target surface vimentin on cancer cells. Nanomedicine (Lond) 2011, 6(2):351-364

48. Steinmetz NF, Maurer J, Sheng H, Bensussan A, Maricic I, Kumar V, Braciak TA: Two domains of vimentin Are expressed on the surface of lymph node, bone and brain metastatic prostate cancer lines along with the putative stem cell marker proteins CD44 and CD133. Cancers (Basel) 2012, 3(3):2870-2885.

49. Dent R, Trudeau M, Pritchard Kl, Hanna WM, Kahn HK, Sawka CA, Lickley LA, Rawlinson E, Sun P, Narod SA: Triple-negative breast cancer: clinical features and patterns of recurrence. Clin Cancer Res 2007, 13(15 Pt 1):4429-4434.

50. Chacon RD, Costanzo MV: Triple-negative breast cancer. Breast Cancer Res 2010, 12(2):S3.

51. Foulkes WD, Smith IE, Reis-Filho JS: Triple-negative breast cancer. N Engl Med 2010, 363(20):1938-1948

52. manjunath $\mathrm{s}$ : Estrogen receptor negative breast cancer in India: do we really have higher burden of this subtype? Indian J Surg Oncol 2011, 2:122-125.

53. Khokhar A: Breast cancer in India: where do we stand and where do we go? Asian Pac J Cancer Prev 2012, 13(10):4861-4866.

54. Rao C, Shetty J, Prasad KH: Immunohistochemical profile and morphology in triple - negative breast cancers. J Clin Diagn Res 2013, 7(7):1361-1365.

55. Carney DN, Gazdar AF, Minna JD: Positive correlation between histological tumor involvement and generation of tumor cell colonies in agarose in specimens taken directly from patients with small-cell carcinoma of the lung. Cancer Res 1980, 40(6):1820-1823.

56. Nishida $H$, Ueno $H$, Park JW, Yano T: Isochromosome $\mathrm{i}(17 \mathrm{q})$ as a sole cytogenetic abnormality in a case of leukemic transformation from myelodysplastic syndrome (MDS)/myeloproliferative diseases (MPD). Leuk Res 2008, 32(8):1325-1327.

57. Becher R, Carbonell F, Bartram CR: Isochromosome 17q in Ph1-negative leukemia: a clinical, cytogenetic, and molecular study. Blood 1990, 75(8):1679-1683.

58. Park AK, Lee SJ, Phi JH, Wang KC, Kim DG, Cho BK, Haberler C, Fattet S, Dufour C, Puget S, Sainte-Rose C, Bourdeaut F, Grill J, Delattre O, Kim SK, Park WY: Prognostic classification of pediatric medulloblastoma based on chromosome 17p loss, expression of MYCC and MYCN, and Wnt pathway activation. Neuro Oncol, 14(2):203-214.

59. Polianskaya GG, Vakhtin lu B: The karyotypic structure of cell populations in vitro as an integral system. Tsitologiia 2003, 45(2):115-131.

60. Wolman SR: Karyotypic progression in human tumors. Cancer Metastasis Rev 1983, 2(3):257-293

61. Wolman SR, Heppner GH: Genetic heterogeneity in breast cancer. J Natl Cancer Inst 1992, 84(7):469-470

62. Lung FW, Lee TM, Shu BC, Chang FH: p53 codon 72 polymorphism and susceptibility malignancy of colorectal cancer in Taiwan. J Cancer Res Clin Oncol 2004, 130(12):728-732

63. Pietsch EC, Humbey O, Murphy ME: Polymorphisms in the p53 pathway. Oncogene 2006, 25(11):1602-1611

64. Papadakis EN, Dokianakis DN, Spandidos DA: p53 codon 72 polymorphism as a risk factor in the development of breast cancer. Mol Cell Biol Res Commun 2000, 3(6):389-392.

65. Tandle AT, Sanghvi V, Saranath D: Determination of p53 genotypes in oral cancer patients from India. Br J Cancer 2001, 84(6):739-742.

66. Wu HC, Chang CH, Chen HY, Tsai FJ, Tsai JJ, Chen WC: p53 gene codon 72 polymorphism but not tumor necrosis factor-alpha gene is associated with prostate cancer. Urol Int 2004, 73(1):41-46.

67. Mitra S, Sikdar N, Misra C, Gupta S, Paul RR, Roy B, Panda CK, Roychoudhury S: Risk assessment of p53 genotypes and haplotypes in tobaccoassociated leukoplakia and oral cancer patients from eastern Idia. Int J Cancer 2005, 117(5):786-793.

68. Rogounovitch TI, Saenko VA, Ashizawa K, Sedliarou IA, Namba H, Abrosimov AY, Lushnikov EF, Roumiantsev PO, Konova MV, Petoukhova NS, Tchebotareva IV, Ivanov VK, Chekin SY, Bogdanova TI, Tronko MD, Tsyb AF, Thomas GA, Yamashita S: TP53 codon 72 polymorphism in radiationassociated human papillary thyroid cancer. Oncol Rep 2006, 15(4):949-956.

69. Omori S, Yoshida S, Kennedy SH, Negoro K, Hamana S, Barlow DH, Maruo T: Polymorphism at codon 72 of the $\mathrm{p} 53$ gene is not associated with endometriosis in a Japanese population. J Soc Gynecol Investig 2004, 11(4):232-236

70. Langerod A, Bukholm IR, Bregard A, Lonning PE, Andersen TI, Rognum TO, Meling Gl, Lothe RA, Borresen-Dale AL: The TP53 codon 72 polymorphism may affect the function of TP53 mutations in breast carcinomas but not in colorectal carcinomas. Cancer Epidemiol Biomarkers Prev 2002 11(12):1684-1688

71. Perez LO, Abba MC, Dulout FN, Golijow CD: Evaluation of p53 codon 72 polymorphism in adenocarcinomas of the colon and rectum in La Plata, Argentina. World J Gastroenterol 2006, 12(9):1426-1429.

72. He XF, Su J, Zhang Y, Huang X, Liu Y, Ding DP, Wang W, Arparkorn K: Association between the $\mathrm{p} 53$ polymorphisms and breast cancer risk: meta-analysis based on case-control study. Breast Cancer Res Treat 2010, $130(2) \cdot 517-529$

73. Doosti A: Association of the p53 codon 72 polymorphism with colorectal cancer in South West of Iran. Scientific Research and Essays 2011, 6(15):3148-3152.

74. Siddiqi A, Khan DA, Khan FA, Naveed AK: Impact of CYP2C9 genetic polymorphism on warfarin dose requirements in Pakistani population. Pak J Pharm Sci 2010, 23(4):417-422

75. Borg A, Haile RW, Malone KE, Capanu M, Diep A, Torngren T, Teraoka S, Begg CB, Thomas DC, Concannon P, Mellemkiaer L, Bernstein L, Tellhed L, Xue S, Olson ER, Liang X, Dolle J, Borrensen-Dale AL, Bernstein JL: Characterization of BRCA1 and BRCA2 deleterious mutations and variants of unknown clinical significance in unilateral and bilateral breast cancer: the WECARE study. Hum Mutat 2010, 31(3):E1200-E1240.

76. Durocher F, Shattuck-Eidens D, McClure M, Labrie F, Skolnick MH, Goldgar DE, Simard J: Comparison of BRCA1 polymorphisms, rare sequence variants 
and/or missense mutations in unaffected and breast/ovarian cancer populations. Hum Mol Genet 1996, 5(6):835-842.

77. Kim TJ, Lee KM, Choi CH, Lee JW, Lee JH, Bae DS, Kim BG: Germline mutations of BRCA1 in two Korean hereditary breast/ovarian cancer families. Oncol Rep 2006, 15(3):565-569.

78. Zhou YZ, Sun Q, Lin SQ, Wang J, Liu B, Li JX, Zhou YD, Ye J, Han H, Fang FD: Germline mutations in the BRCA1 and BRCA2 genes from breast cancer families in China Han people. Zhonghua Yi Xue Za Zhi 2004, 84(4):294-298.

79. Ginestier C, Hur MH, Charafe-Jauffret E, Monville F, Dutcher J, Brown M, Jacquemier J, Viens P, Kleer CG, Liu S, Schott A, Hayes D, Birnbaum D, Wicha MS, Dontu G: ALDH1 is a marker of normal and malignant human mammary stem cells and a predictor of poor clinical outcome. Cell Stem Cell 2007, 1(5):555-567.

80. Li C, Heidt DG, Dalerba P, Burant CF, Zhang L, Adsay V, Wicha M, Clarke MF, Simeone DM: Identification of pancreatic cancer stem cells. Cancer Res 2007, 67(3):1030-1037.

81. Hermann PC, Huber SL, Herrler T, Aicher A, Ellwart JW, Guba M, Bruns Cf Heeschen C: Distinct populations of cancer stem cells determine tumor growth and metastatic activity in human pancreatic cancer. Cell Stem Cell 2007, 1(3):313-323.

82. Singh SK, Clarke ID, Terasaki M, Bonn VE, Hawkins C, Squire J, Dirks PB: Identification of a cancer stem cell in human brain tumors. Cancer Res 2003, 63(18):5821-5828.

83. Son MJ, Woolard K, Nam DH, Lee J, Fine HA: SSEA-1 is an enrichment marker for tumor-initiating cells in human glioblastoma. Cell Stem Cell 2009, 4(5):440-452

84. O'Brien CA, Pollett A, Gallinger S, Dick JE: A human colon cancer cell capable of initiating tumour growth in immunodeficient mice. Nature 2007, 445(7123):106-110

85. Dalerba P, Dylla SJ, Park IK, Liu R, Wang X, Cho RW, Hoey T, Gurney A, Huang EH, Simeone DM, Shelton AA, Parmiani G, Castelli C, Clarke MF: Phenotypic characterization of human colorectal cancer stem cells. Proc Natl Acad Sci U S A 2007, 104(24):10158-10163.

86. Ricci-Vitiani L, Lombardi DG, Pilozzi E, Biffoni M, Todaro M, Peschle C, De Maria R: Identification and expansion of human colon-cancer-initiating cells. Nature 2007, 445(7123):111-115.

87. Yang ZF, Ho DW, Ng MN, Lau CK, Yu WC, Ngai P, Chu PW, Lam CT, Poon RT, Fan ST: Significance of CD90+ cancer stem cells in human liver cancer. Cancer Cell 2008, 13(2):153-166.

88. Prince ME, Sivanandan R, Kaczorowski A, Wolf GT, Kaplan MJ, Dalerba P, Weissman IL, Clarke MF, Ailles LE: Identification of a subpopulation of cells with cancer stem cell properties in head and neck squamous cell carcinoma. Proc Natl Acad Sci U S A 2007, 104(3):973-978.

89. Bapat SA, Mali AM, Koppikar CB, Kurrey NK: Stem and progenitor-like cells contribute to the aggressive behavior of human epithelial ovarian cancer. Cancer Res 2005, 65(8):3025-3029.

90. Fong MY, Kakar SS: The role of cancer stem cells and the side population in epithelial ovarian cancer. Histol Histopathol, 25(1):113-120.

91. Schatton T, Murphy GF, Frank NY, Yamaura K, Waaga-Gasser AM, Gasser M, Zhan Q, Jordan S, Duncan LM, Weishaupt C, Fuhlbrigge RC, Kupper TS, Sayegh MH, Frank MH: Identification of cells initiating human melanomas. Nature 2008, 451(7176):345-349.

92. Fang D, Nguyen TK, Leishear K, Finko R, Kulp AN, Hotz S, Van Belle PA, Xu X, Elder $\mathrm{DE}$, Herlyn M: A tumorigenic subpopulation with stem cell properties in melanomas. Cancer Res 2005, 65(20):9328-9337.

doi:10.1186/1475-2867-14-14

Cite this article as: Pandrangi et al:: Establishment and characterization of two primary breast cancer cell lines from young Indian breast cancer patients: mutation analysis. Cancer Cell International 2014 14:14.

\section{Submit your next manuscript to BioMed Central and take full advantage of:}

- Convenient online submission

- Thorough peer review

- No space constraints or color figure charges

- Immediate publication on acceptance

- Inclusion in PubMed, CAS, Scopus and Google Scholar

- Research which is freely available for redistribution

Submit your manuscript at www.biomedcentral.com/submit
Biomed Central 